\title{
ARTICLES
}

\section{Collateralizing Privacy}

\author{
Xuan-Thao N. Nguyen
}

Collateralizing privacy is a pervasive conduct committed by many on-line companies. Yet most don't even realize that they are engaging in collateralizing privacy. Worse yet, governmental agencies and consumer groups are not even aware of the violation of on-line consumer privacy by the collateralization of privacy. Professor Nguyen argues that collateralizing privacy occurs under the existing privacy regime and the architecture of article 9 of the Uniform Commercial Code. Professor Nguyen critiques the violation of privacy through collateralization dilemmas and proposes a solution involving modifications of the contents of the financing statement and security agreement in secured transactions where consumer information is used as collateral and classified as a general intangible.

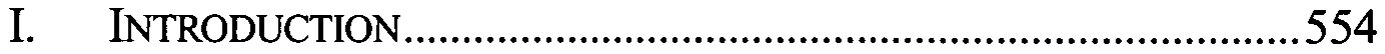

II. E-COMMERCE, PRIVACY ASSETS, AND POLICY ...........................557

A. Status of E-commerce ...................................................557

B. Consumer E-confidence and Privacy Concerns ...............559

C. The Valuable Privacy Asset .............................................564

D. The Few Notable On-line Consumer Privacy Cases.........567

E. Samples of Privacy Policy Statements..............................570

III. THE COLLATERALIZATION SCHEME ........................................571

A. Examples of Collateralization.........................................571

B. Article 9 of the Uniform Commercial Code .....................573

C. Consumer Databases as Collateral ..................................576

IV. THE PERVASIVE VIOLATION OF PRIVACY ...................................581

A. The Security Agreement................................................581

B. The Financing Statement...............................................585

C. The Debtor's Obligation: The Daily Violation .................587

1. For the Benefit of the Secured Party..........................587

2. Privacy Violations in the Event of Default ................589

3. Privacy Violations Without Default ............................591

* Associate Professor of Law, Southern Methodist University, Dedman School of Law. J.D. Northeastern University School of Law; B.A. Oberlin College. Intellectual Property Associate, Fried, Frank, Harris, Shriver \& Jacobson (New York City); Intellectual Property Associate, Pryor, Cashman, Sherman \& Flynn, LLP (New York City). The generous writing grant provided by SMU Dedman School of Law enabled the author to develop the scholarship reflected in this Article. Many thanks to my friend, Professor Ben Davis, for wonderful discussions on e-commerce, e-confidence, and privacy. Many thanks to Bruce Muck, Head of Research Services, SMU Underwood Law Library, for his professional research support. Special thanks to Erik Darwin Hille and our son Khai-Leif Nguyen-Hille for their love, kindness, and support. 
4. Private Default and Public Violation.........................592

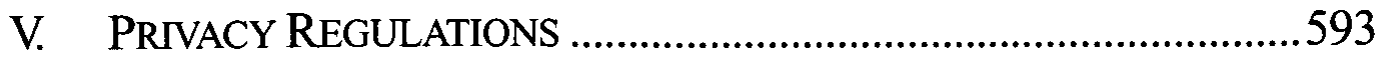

A. Industry Self-Regulation and Its Failure..........................593

B. The European Union's Approach \& Its Failure.................595

VI. FACING THE PRIVACY DILEMMA: A PROPOSAL .........................599

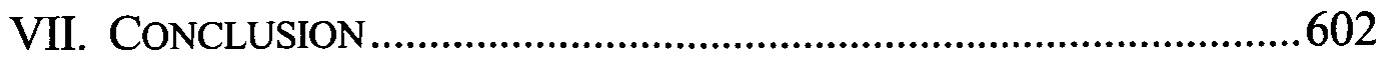

\section{INTRODUCTION}

Privacy today incorporates the consumer's expectations about and knowledge of the accessibility of personal information gathered by online companies.' Privacy is violated when Internet companies collateralize consumer information, altering the promised limitation of accessibility posted on Web sites. Indeed, privacy penetrates the heart of collateralization of corporate assets in secured transactions. ${ }^{2}$ It hides behind private transactions between the parties to the contract in that the public does not have access to the terms of the transactions to decipher the violation. ${ }^{3}$ The lack of knowledge about the violation results from an omission at the core of article 9 of the Uniform Commercial Code: there is no requirement under article 9 to file the secured transaction contract-the security agreement-in a central place for public scrutiny. ${ }^{4}$ Further, the code does not mandate that the document that is required for filing-the financing statementdisclose that consumer information is being used as collateral. ${ }^{5}$ This allows the violation of consumer privacy to take place seamlessly and pervasively. ${ }^{6}$

Welcome to the complexity of consumer on-line privacy. Welcome to the invisible world of collateralization of privacy.

Consider this scenario: you are the Chief Executive Office of a major Internet company that has been fighting very hard to survive the sluggish economy. You are happy to learn that in the year 2002 consumer on-line spending was substantially higher than in 2001. ${ }^{7}$ You

1. See Daniel J. Solove, Privacy and Power: Computer Databases and Metaphors for Information Privacy, 53 STAN. L. REV. 1393, 1457 (2001) (arguing that courts must recognize that accessibility and use of consumer information threaten consumer privacy).

2. See discussion infra Parts III \& IV.

3. See discussion infra Part IV.

4. See discussion infra Part IV.A.

5. See discussion infra Part IV.B.

6. See discussion infra Part IV.C.

7. Lisa Gill, Reports: 2002 E-Commerce Spending Skyrocketed, E-COMMERCE TIMES, Jan. 2, 2003 (reporting the results of surveys conducted by comScore Media Metrix, a Web traffic measurement firm, that e-commerce growth in 2002 topped seventy-four billion 
are delighted that many surveys have indicated that on-line spending will increase ${ }^{8}$ and more nonusers will log on the Internet in 2003. ${ }^{9}$ You want your company to grow and gain a profit in 2003 and beyond. You want to keep your existing customers and lure new consumers to your Web site. You are confident that your company's privacy policy, posted on your Web site, will provide consumers with confidence in their on-line transactions. ${ }^{10}$ Your company has been strictly adhering to the privacy policy statement that it neither sells nor licenses consumer information to others." You have assisted your subordinates in drafting the privacy policy statement and remain active in monitoring your employees' adherence to the policy. You feel proud and good about your company.

Then, you receive a letter from several powerful consumer groups along with an indication that they have also sent a copy of the letter to the Federal Trade Commission (FTC). The letter states that your company is violating the privacy policy statement even though the letter admits that your company has neither sold nor rented consumer information to others. The letter, however, asserts that your company has been collateralizing privacy. What is collateralizing privacy? How

dollars, a thirty-nine percent increase from 2001), at http://www.ecommercetimes.com/perl/ story/20353.html; Bob Woods, E-Commerce's 1.3 Percent Problem, E-Commerce Times, Jan. 20, 2003 (reporting the latest U.S. Census Bureau figures on the increase in e-commerce spending for 2002) at http://www.ecommercetimes.com/perl/story/20506.html.

8. Lisa Gill, Study: Consumers Plan More Online Spending in 2003, E-COMMERCE TIMES, Jan. 20, 2003 (reporting the results of a survey conducted by ACNielsen showing that consumer confidence in on-line products and services remains high, more consumers plan to spend money on-line during the first quarter of 2003, and there will be more first time online consumers), at http://www.ecommercetimes.com/perl/story/20512.html.

9. The UCLA Internet Project, conducted by the UCLA Center for Communication Policy, surveyed 2000 U.S. households and revealed that forty-seven percent of nonusers plan to go on-line in 2003. A summary of the survey and detailed findings are available in UCLA CTR. FOR COMMUNICATION POLICY, THE UCLA INTERNET REPORT: SURVEYING THE DigITAL FUTURE: YEAR THREE 8 (2003) [hereinafter UCLA INTERNET REPORT], at http://www.ccp. ucla.edu/pdf/UCLA-Internet-Report-year-Three.pdf.

10. It is now common that many Internet companies engage in self-regulation by posting a privacy statement on their Web sites and promising to follow the privacy practices indicated in the policy statement. See generally Solove, supra note 1, at 1448 \& n.297 (noting the trend that more Web sites are collecting personal information, and that more Web sites are posting privacy policies).

11. The Federal Trade Commission (FTC) has initiated actions against Internet companies for deceptive practices when they have engaged in conduct that violates their representations to the public. For example, the FTC brought an action against Toysmart.com for attempting to sell consumer information to others while its privacy policy statement assured the public that the company would not engage in such acts. FTC v. Toysmart.com, LLC, No. CIV. A. 00-CV11341RGS, 2000 WL 1523287, at*1 (D. Mass. Aug. 21, 2000); see also In re GeoCities, File No. 9823015, 1998 WL 473217 (F.T.C. 1998) (requiring GeoCities to agree to refrain from misrepresenting its use and collection of consumer information). 
did you, your counsel, and thousands of Internet companies not have the faintest idea that collateralizing privacy occurs every day, rendering privacy policy statements deceptive? You like neither the FTC nor the negative publicity.

This Article argues that collateralizing privacy occurs under the existing privacy regime and article 9 of the Uniform Commercial Code, rendering privacy policies posted on Web sites misleading and deceptive. The discussion will proceed as follows: Part II examines the current status of e-commerce and how the consumer database has become a valuable privacy asset to on-line companies. This Part also analyzes the existing self-regulation approach to privacy by examining notable on-line privacy cases and surveying privacy policy statements posted on Web sites.

Part III focuses on the collateralization process under article 9 of the Uniform Commercial Code. This Part discusses how a consumer database is recognized as property and how a creditor's security interest becomes valid and enforceable against third parties under article 9, in contrast to the intellectual-property-rights regime.

Part IV analyzes how collateralizing consumer databases becomes collateralization of privacy. The peculiarity of the collateralization-of-privacy scheme is that many Internet companies will probably deny that they are engaging in such conduct. Internet companies will proudly defend their privacy policy statements in their assertion that they have always adhered to a self-regulatory privacy standard. They are not violating their own privacy statements because they have neither sold nor licensed their customer information to others. Ironically, though collateralization of an asset in a secured financial transaction is not a direct sale of the asset to the creditor, ${ }^{12}$ nevertheless, the principle of freedom of contract and the procedures set forth in article 9 of the Uniform Commercial Code facilitate the pervasive violation of consumer privacy through collateralization of consumer information. ${ }^{13}$

Part $\mathrm{V}$ examines and compares the two approaches to privacy practiced by the United States and the European Union. Both approaches only scratch the surface of privacy violations, failing to recognize collateralization of privacy.

Part VI addresses the dilemma of collateralization of consumer databases and suggests a proposal to end the violation of consumer

12. See discussion infra IV.A.

13. See discussion infra IV.C. 
privacy in the collateralization context. Because secured finance transactions are fundamental to how companies obtain financing, Internet companies will continue to collateralize corporate assets, including consumer databases. On-line privacy violations, however, cannot be ignored, particularly when the practice of collateralizing privacy is pervasive and legitimized under the existing procedures of article 9. Addressing the dilemma requires modifications to article 9 as well as to the present disclosure regimes under the United States and European Union approaches.

The Article concludes that collateralization of privacy is an example of an invisible violation of privacy. The root of privacy collateralization lies in the use of consumer databases as collateral to secure a loan or obligation. There are perhaps additional violations of privacy, of which the public is unaware, that occur as the Internet continues to penetrate and permeate daily existence. Perhaps it is not too late for a more comprehensive agenda to address on-line privacy.

\section{E-COMMERCE, PrIVACY ASSETS, AND POLICY}

\section{A. Status of E-commerce}

The globalization of electronic communication and commerce has fostered an increase in the numbers of Web sites and users, despite the downturn in the economy. ${ }^{14}$ Compared to the year 2000, when the Internet-based economy bubble deflated, the World Wide Web has added about ten million new Web sites to its system in the last two years. ${ }^{15}$ Presently, there are about 182 million Internet users in North America and 605 million Internet users worldwide. ${ }^{16}$

With regard to on-line spending, consumer spending has increased substantially compared to $2001,{ }^{17}$ and the number has been

14. See A. Michael Froomkin, Habermas@discourse.net: Toward a Critical Theory of Cyberspace, 116 HARV. L. REV. 749, 782 (2003) (observing the increase in the number of Internet users, readable Web pages, and aggregation of Internet data traffic).

15. See Robert H. Zakon, Hobbes' Internet Timeline v6.1 (tracking the development of the Internet and the World Wide Web), at http://www.zakon.org/robert/internet/timeline (last updated July 23, 2003). In December 2000, there were 25,677,581 Web sites on the World Wide Web. Id. Two years later, as of December 2002, there were 35,543,105 Web sites on the World Wide Web. Id. In January 2001, there were 109,574,429 Internet hosts. Id. As of January 2003, the number had jumped to 171,638,297. See Internet Software Consortium, Internet Domain Survey: Number of Internet Hosts, at http://www.isc. org/ds/host-count-history.html (last visited Sept. 26, 2003).

16. Nua Internet Surveys, How Many Online?, at http://www.nua.com/surveys/how_ many_online/index.html (last visited Oct. 23, 2003).

17. The UCLA Internet Project's UCLA Internet Report: Surveying the Digital Future: Year Three (Surveying the Digital Future) surveyed the same 2000 U.S. households 
projected to increase in $2003 .{ }^{18}$ Indeed, e-commerce spending reached $\$ 74$ billion in 2002, a thirty-nine percent increase from 2001. ${ }^{19}$ Recent surveys have indicated that consumers plan to spend more money online in 2003. ${ }^{20}$ Specifically, in the first quarter of 2003, U.S. consumers are projected to spend $\$ 14.8$ billion on-line. ${ }^{21}$ Also, a new study conducted by the University of California at Los Angeles Center for Communication Policy reveals that, although the Internet has only been popular for approximately eight years, it has outranked all major forms of media as a source of information. ${ }^{22}$

An explanation for such growth lies in the accelerated internationalization and commercialization of the Internet. $^{23}$ Furthermore, such an increase may be the consequence of technological improvements that have attracted more users to the Internet and unique visitors to Web sites. ${ }^{24}$ Undoubtedly, the

annually for the last three years and found that consumers spent substantially more money on-line in 2002 than in 2001. UCLA INTERNET REPORT, supra note 9, at 10, 86.

18. See Gill, supra note 8 (reporting the increase in consumers' confidence and spending).

19. Gill, supra note 7 (reporting the findings of Web traffic measurement firm comScore Media Metrix that e-commerce growth in 2002 topped $\$ 74$ billion, a thirty-nine percent increase from 2001); Woods, supra note 7 (reporting the latest U.S. Census Bureau figures on the increase in e-commerce spending for 2002).

The Census Bureau explains in its Frequently Asked Questions (FAQ) section that ecommerce figures do not include on-line publishing and broadcasting spending. U.S. Census Bureau, E-Commerce Frequently Asked Questions, at http://www.census.gov/mrts/www/ efaq.html (last revised Sept. 9, 2003). The Census Bureau conducts a monthly survey to estimate total retail sales and e-commerce sales. Id. The survey, however, "excludes companies conducting non-retail operations such as travel, ticketing, and financial services." Id. This suggests that the e-commerce figure does not reflect all on-line spending.

20. News Release, ACNielsen, Yahoo! and ACNielsen Release Seventh Quarterly Wave of Internet Confidence Index (Jan. 17, 2003) [hereinafter ACNielsen new Release] (reporting that fifty-six percent of consumers intend to shop on-line in the first quarter of 2003), at http://www.acnielsen.com/news/corp/2003/20030117.htm. This number is higher than a year ago, at forty-seven percent. Id; see also Gill, supra note 8 (reporting the results of a survey conducted by ACNielsen showing high consumer confidence in on-line products and services for 2003).

21. ACNielsen News Release, supra note 20 (reporting the results of its latest quarterly survey of 1000 adults in the United States).

22. UCLA INTERNET REPORT, supra note 9, at 9, 35; see also Dawn Kawamoto, Net Ranks as Top Information Source, CNET NEwS.COM, Feb. 3, 2003 (reporting that the study Surveying the Digital Future shows that both Internet users and nonusers rank the Internet as the most important form of media as a source of information (discussing UCLA INTERNET REPORT, supra note 9, at 9, 35)), available at http://zdnet.com.com/2100-1105-982995.html.

23. See Froomkin, supra note 14, at 781-82 (observing the transformation of the Internet).

24. See Gill, supra note 8 (reporting that consumers with high-speed Internet connections expressed the most confidence in their on-line transactions). 
convenience and efficiency of the on-line environment lure more consumers to the Internet for on-line transactions. ${ }^{25}$

The latest glimpse of good news about the Internet and ecommerce spending suggests that despite the sluggish economy, more consumers and businesses are turning to the on-line medium for various types of commercial transactions. ${ }^{26}$ The increase confirms that the Internet and e-commerce are becoming ever a part of our daily lives. ${ }^{27}$

\section{B. Consumer E-confidence and Privacy Concerns}

The growth of e-commerce spending ${ }^{28}$ which many companies would like to see, hinges in part on the level of consumer confidence in the on-line environment. ${ }^{29}$ Consumer privacy has been an international concern, not confined to the United States and its

25. Id.; see also ACNielsen News Release, supra note 20 (reporting that broadband consumers continue to be more confident than dial-up modem consumers and that the key factors motivating increased confidence include convenience and high comfort levels with credit card usage).

26. ACNielsen News Release, supra note 20.

27. See Woods, supra note 7 (reporting the latest U.S. Census Bureau figures which suggest that the Internet has become an important part of daily lives); see also ACNielsen News Release, supra note 20 ("The number of consumers turning to the Internet to shop continues to increase."); Kawamoto, supra note 22 (reporting that the UCLA Internet Project surveyed 2000 U.S. households, which ranked the Internet as the most important medium for obtaining information). The UCLA study also revealed that forty-seven percent of nonusers plan to go on-line in 2003. UCLA INTERNET REPORT, supra note 9, at 8.

28. Though surveys reveal that the Internet permeates social and economic fabrics, ecommerce spending remains a very modest percentage of the overall total retail sales. See Woods, supra note 7 (investigating why e-commerce constitutes a very small portion of total retail sales figures). Slow connections to the Internet, basic problems relating to the search engines, and the consumer's desire to maintain social interactions with others in brick-andmortar transactions are attributable to the small percentage of e-commerce spending in total retail sales figures. Id. The main reason, however, was noted by the FTC in its report to Congress in 1998: "[I]f growing consumer concerns about online privacy are not addressed, electronic commerce will not reach its full potential." FED. TRADE COMM'N, PRIVACY ONLINE: A REPORT TO CONGRESS 43 (1998), available at http://www.ftc.gov/reports/privacy3/ priv-23a.pdf

29. See Mozelle Thompson, Keynote Address: The Federal Trade Commission and Regulating E-Commerce, 16 ST. JOHN's J. LEGAL COMMENT. 609, 612 (2002) ("Privacy and data protection are key elements that are necessary for realizing the opportunities presented by the new economy because they are more and more often viewed as proxies nowadays for consumer trust and confidence."); Thomas T. Reith III, Note, Consumer Confidence: The Key to Successful E-Commerce in the Global Marketplace, 24 Suffolk TRANSNAT'L L. REv. 467, 481 (2001) (comparing the U.S. and European Union approaches in on-line privacy policy, and stating that "the electronic market must have confident consumers willing to purchase the goods and services via the Internet. Without the confident consumers to engage in the economic avenues offered by the Internet, e-commerce might falter." (footnotes omitted)). 
consumers. ${ }^{30}$ Ensuring consumer privacy remains an important element in building necessary consumer confidence in e-commerce. ${ }^{31}$ Indeed, the Consumer Internet Barometer, a quarterly survey of 10,000 households by NFO WorldGroup, Forrester Research, and The Conference Board, indicates that the majority of consumers at the end of 2002 are still very concerned about the privacy of their on-line personal information. ${ }^{32}$ Only twenty-five percent of the consumers surveyed expressed a belief that their personal information would be

30. European governments and consumers have expressed grave concerns about consumer privacy. The European Union has been collecting information and examining ways to increase consumer confidence in e-commerce. The European Union is expected to propose standards for e-commerce for the EU countries in 2003. Anandashankar Mazumdar, European Commission to Take Up Issue of EU-Wide Trustmark Proposal in Spring, 8 ELECTRONIC COM. \& L. REP. (BNA) 90, 90-91 (2003) (reporting the EU's progress on the development of standards for electronic commerce to increase consumer confidence). The EU's eConfidence project is available at the European Commission's eConfidence Forum, at http://econfidence.jrc.it (last visited Oct. 23, 2003).

31. See, e.g., NFO WorldGroup, Forrester RESEARCH, \& THE CONFERENCE BOARD, CONSUMER INTERNET BAROMETER SURVEY: FOURTH QUARTER 2002, fig. 3: Consumer Trust and Satisfaction by Activity (on file with author) [hereinafter CONSUMER INTERNET BAROMETER SURVEY] (indicating that the majority of consumers continue to be concerned about their trust in on-line communications and transactions). Lynn Franco, Director of the Consumer Research Center of The Conference Board, one of the three companies conducting the Consumer Internet Barometer survey, states that the "[1]ack of trust has long been a major barrier to engaging in on-line transactions .... Consumers' concern about privacy of their personal information has a significant influence on their willingness to engage in business exchanges online." Press Release, Consumer Internet Barometer, More Consumers Trust That Their Online Transactions are Safe (Jan. 2, 2003) [hereinafter Consumer Internet Barometer Press Release] (internal quotations omitted), at http://www.consumerinternetbarometer.us/press02.htm. Ms. Franco is optimistic that "this trust barrier is beginning to erode," as reflected in the increase from 27.5 percent of consumers in the last quarter of 2001 to thirty-three percent of consumers in the last quarter of 2002 expressing trust that their on-line financial transactions are safe. Id. (internal quotations omitted).

32. The present on-line consumer privacy concern, as indicated by the Consumer Internet Barometer survey, demonstrates that such concern has been persistent over time. Press Release, Consumer Internet Barometer More Consumers Going Online, But Trust Is a Major Concern (Oct. 16, 2002), at http://www.consumerinternetbarometer.us/press01/htm. Indeed, in the early years of electronic commerce, on-line consumer privacy was identified as a critical issue for the development and growth of electronic commerce. See Joel R. Reidenberg, Restoring Americans' Privacy in Electronic Commerce, 14 BERKELEY TECH. L.J. 771, 771-72 (1999) (observing that during "the last few years, an overwhelming majority of Americans report that they have lost control of their personal information and that current laws are not strong enough to protect their privacy," and that "privacy has become the critical issue for the development of electronic commerce"). In 1998, the FTC acknowledged that, based on consumer surveys, "consumers will continue to distrust online companies and will remain wary of engaging in electronic commerce until meaningful and effective consumer privacy protections are implemented in the online marketplace. If such protections are not implemented, the online marketplace will fail to reach its full potential." FED. TRADE COMM'N, supra note 28 , at 3-4. 
safe during personal communication, research, and purchase of products on-line. ${ }^{33}$ About twenty-seven percent of the consumers felt secure in performing work-related activities on-line. ${ }^{34}$ Only one-third of the consumers expressed trust in on-line financial transactions. ${ }^{35}$ These statistics, compared to survey results of 2001, reflect a very modest increase in consumer trust. ${ }^{36}$ Overall, the majority of Internet users continue to distrust on-line financial transactions. ${ }^{37}$ The burden is on Internet companies to provide consumers with an improved comfort level with consumer privacy. ${ }^{38}$

Many in the computer industry believe that consumers have no legitimate privacy expectations and that they should "get over it."39 Some believe that the government has already addressed consumer privacy issues through its enforcement mechanisms, ${ }^{40}$ and that

33. CONSUMER INTERNET BAROMETER SURVEY, supra note 31, fig. 3: Consumer Trust and Satisfaction by Activity.

34. Id.

35. CONSUMER INTERNET BAROMETER PRESS RELEASE, supra note 31 .

36. Most notably, the trust levels among consumers for on-line transactions have improved from $27.5 \%$ in the fourth quarter of 2001 , expressing trust that their on-line financial transactions are safe, to thirty-three percent in the fourth quarter of 2002. CONSUMER INTERNET BAROMETER SURVEY, supra note 31, fig. 3: Consumer Trust and Satisfaction by Activity; see also Consumer Internet Barometer, Press Release, supra note 31.

37. See CONSUMER INTERNET BAROMETER SURVEY, supra note 31, fig. 6: Internet Trust and Satisfaction; Consumer Internet Barometer, Press Release, supra note 31.

38. Currently, on-line consumer privacy policy is self-regulated by Internet companies. See Aileen A. Pisciotta \& Karlyn D. Stanley, Leading Internet Developments in 2002, in 20th ANNual Institute on Telecommunications: Policy \& Regulation 129, 168 (PLI Intellectual Prop. Course Handbook Series No. G-731, 2002) (stating that the United States does not have an omnibus federal privacy law governing Internet companies' privacy statements and practices). The self-regulatory approach has long been criticized by many experts. Professor Joel R. Reidenberg has observed that reports of consumers losing control of their personal information have become common, and has criticized the ineffectiveness of leaving on-line privacy oversight in the hands of the Internet companies. Reidenberg, supra note 32, at 771-73; see also ACNielsen News Release, supra note 20 (reporting that more consumers continue to use the Internet and that such increase demonstrates "how intrinsic the Web is becoming to daily life, and how important it is for online businesses to deliver a quality experience").

39. See Polly Sprenger, Sun on Privacy: 'Get Over It', WIREd News, Jan. 26, 1999 (reporting the remark, made by Scott McNealy, CEO of Sun Microsystems, regarding the consumer privacy debate), at http://www.wired.com/news/politics $/ 0,1283,17538,00$ html . McNealy's statement is a confirmation of the belief shared by many businesses. See Toby Lester, The Reinvention of Privacy, ATLANTIC ONLINE, Mar. 2001 ("There's a general sense, too, that businesses in the modern free market are indifferent to the threats their new technologies pose to privacy."), at www.theatlantic.com/issues/2001/03/lester-p1.htm.

40. See Anthony Rollo, The New New Litigation Thing: Consumer Privacy, in 1 Consumer Financial Services Litigation 2002, at 9, 48-71 (Pli Corp. Law \& Practice Course Handbook Series No. B-1301, 2002) (analyzing the "FTC's [t]rail [b]lazing [a]ctivities [a]s [d]efacto [f]ederal [r]egulator [o]f [i]nternet [p]rivacy"). The FTC has become the "leading watchdog agency" for consumer privacy since the creation of the 
businesses and industries have already adopted various means to achieve privacy for consumers. ${ }^{41}$ Indeed, the government provides some enforcement measures to protect consumer privacy through the FTC. ${ }^{42}$ Specifically, the FTC has taken action in a few cases against Internet companies that publicly attempted to sell consumer information to third parties and thus allegedly violated consumer privacy statements posted on their own Web sites. ${ }^{43}$

Moreover, consumer privacy concerns have been pushed aside in the aftermath of the deflation of the Internet economy bubble in 2000 and the September 11, 2001 attacks. $^{44}$ Concerns for national security have overshadowed privacy issues in general. ${ }^{45}$

On-line consumer privacy, nevertheless, remains a complex issue as the Internet, on-line communication, and commerce are still in the development and growth process. ${ }^{46}$ The unknowns remain. More

Internet. Id. at 48. See generally Dean William Harvey \& Amy White, The Impact of Computer Security Regulation on American Companies, 8 TeX. WESLEYAN L. REV. 505 (2002) (analyzing various federal statutes relating to privacy and security of information and what companies should do to comply).

41. Businesses address privacy concerns by posting privacy statements on Web sites. See Rollo, supra note 40, at 30-31 (explaining that the publication of a privacy statement is a voluntary act by the on-line company, but that the statement has a contractually binding effect which the company must follow). "Properly drafted and posted, a privacy statement will limit liability to the Web site operator regarding its information practices; improperly drafted, privacy statements can lead to a litigation nightmare." Id. at 31; Courtenay Youngblood, Comment, A New Millennium Dilemma: Cookie Technology, Consumers, and the Future of the Internet, 11 DEPAUL-LCA J. ART \& ENT. L. 45, 69-72 (2001) (explaining self-policing practices through privacy policies and privacy seal programs).

42. See John F. Delaney, The Law of the Internet: A Summary of U.S. Internet Caselaw and Legal Developments, in RePRESENTING THE New Media COMPANY: GuIDING Your Clients Through a CHANGING ECONOMY 2002, at 29, 229-59 (PLI Intellectual Prop. Course Handbook Series No. G-686, 2002) (discussing the FTC's efforts to increase its enforcement of consumer privacy on the Internet).

43. Id. at 238-43 (tracing the FTC's actions against and investigations of various online companies relating to privacy policy statements).

44. See Pisciotta \& Stanley, supra note 38, at 168 (observing that privacy concern issues became subordinate to national security issues); KEVIN P. CRONIN \& RONALD N. Weikers, Data Security and Privacy LaW: Combating Cyberthreats, § 2:4, at 2-16 (Supp. 2003) (noting the shift in the debate on Internet privacy after the September 11, 2001 attack, and that the USA Patriot Act provides agencies with "expanded powers of electronic surveillance, including interception, collection, and dissemination of electronic communications").

45. The privacy issue is secondary to national security concerns, as demonstrated by the two bills relating to on-line privacy sponsored in 2002. Neither bill fared well in Congress. See Pisciotta \& Stanley, supra note 38, at 170-71 (stating that Senator Fritz Hollings sponsored the On-line Personal Privacy Protection Act of 2002, S. Res. 2201, 107th Cong. (2002), and Representative Cliff Stearns co-sponsored the Consumer Privacy Protection Act of 2002, H.R. Res. 4678, 107th Cong. (2002))).

46. See Jennifer Barrett, Customer Data Integration Technology: A Privacy Solution, COMPUTER \& INTERNET LAW., July 2002, at 8 (stating that "[g]iven the continued growth of e- 
consumers are on-line today. They encounter targeted advertisements and countless spam e-mails. ${ }^{47}$ They, and information about them, are exposed, traced, compared, contrasted, profiled, and analyzed in the increasingly internationalized and commercialized Internet. ${ }^{48}$ As consumers engage in on-line communications and commerce and enjoy the global convenience, connection, and resources of the Internet, the concept of on-line privacy is not about concealment of their conduct and activities on the Internet. ${ }^{49}$ Rather, privacy encompasses the consumer's expectations about and knowledge of the accessibility of their information gathered by on-line companies. ${ }^{50}$

commerce, the proliferation of marketing databases, and a surge of largely negative media attention, consumer privacy concerns are likely to intensify. In light of this, businesses must address privacy issues quickly and legitimately or face more governmental regulation and rising consumer distrust.").

47. Numerous actions against spamming have been brought by Internet service providers. E.g., Verizon Online Servs., Inc. v. Ralsky, 203 F. Supp. 2d 601,604 (E.D. Va. 2002). Internet service providers have been successful in their actions against spamming using the tort claim of trespass to chattel. E.g., Am. Online, Inc. v. LCGM, Inc., 46 F. Supp. 2d 444, 445-46 (E.D. Va. 1998); Hotmail Corp. v. Van\$ Money Pie Inc., 47 U.S.P.Q.2d (BNA) 1020, 1020 (N.D. Cal. 1998); CompuServe Inc. v. Cyber Promotions, Inc., 962 F. Supp. 1015, 1018 (S.D. Ohio 1997). Spamming is one of the most popular forms of on-line advertising and the most bothersome to the consumer. See Scot M. Graydon, Much Ado About SPAM: Unsolicited Advertising, the Internet, and You, 32 ST. MARY's L.J. 77, $81-82$ (2000) (observing the widespread proliferation of spam as a form of advertising); Michael A. Fisher, The Right to Spam? Regulating Electronic Junk Mail, 23 Colum.-VLA J.L. \& ARTS 363, 377 (2000) (examining the regulatory effects and legal doctrines that may impose limits on spamming).

48. See Shaun B. Spencer, Reasonable Expectations and the Erosion of Privacy, 39 SAN DIEGO L. REV. 843, 892-96 (2002) (providing examples of how consumer on-line activities are tracked); FED. TRADE COMM'N, supra note 28, at 22-26.

49. See Patrick F. Gallagher, Note, The Internet Website Privacy Policy: A Complete Misnomer?, 35 SUFFOLK U. L. REv. 373, 376-77 (2001) (explaining the old notion of privacy as territorial solitude, the right to choose, and the right to have personal information remain confidential). Violations of on-line privacy "rights," however, largely involve Internet companies that fail to live up to their self-imposed privacy policies. Id. at 380 .

50. See Solove, supra note 1, at 1457 (critiquing the notion of privacy as secrecy). The European Union has long recognized this premise and adopted the Data Protection Directive in 1996, which provides on-line consumers with notice, choice, access, and control of their information. Council Directive 95/46/EC, 1995 O.J. (L 281) 31, 31-50. The European Union understood that on-line privacy is about whether consumers receive notice of the collection of personal information, choice about participation in such collection, and control over certain sensitive information. See discussion infra Part V.B. Some companies in the database industry believe that if consumers are given access to their data files, they will focus on the accuracy of the data rather than choose to opt out of the database itself. Barrett, supra note 46, at 8-9 (advocating the use of a new technology, in which Customer Data Integration allows consumers to have access to their data files and correct the information about them). 


\section{The Valuable Privacy Asset}

The global and electronic nature of the Internet allows on-line companies, employing the power of a few computers, high speed Internet access, reliable servers, memorable domain names, and visible Web sites to establish their on-line presence. ${ }^{51}$ Instead of owning physical assets, such as the retail stores, headquarters, and warehouses owned by brick-and-mortar companies, on-line companies' assets are often intangibles, including domain names, trademarks, trade secrets, know-hows, copyrights, patents, and customer databases. ${ }^{52}$ The customer database is often viewed as one of the most valuable assets of on-line companies. ${ }^{53}$

With the aid of technology, ${ }^{54}$ Internet companies can aggregate large consumer databases from multiple sources, such as registration

51. See generally A. Mechele Dickerson, From Jeans to Genes: The Evolving Nature of Property of the Estate, 15 BANKR. DEV. J. 285, 299-300 (1999) (observing how the Internet medium is different from the off-line environment and how on-line companies could build their presence on the Internet with few tangible assets).

52. Xuan-Thao N. Nguyen, Commercial Law Collides with Cyberspace: The Trouble with Perfection - Insecurity Interests in the New Corporate Asset, 59 WASH. \& LEE L. REV. 37, 41 (2002) (noting that, due to the nature of cyberspace, Internet companies' most valuable assets are intangibles); William F. Alderman \& John Kanberg, Due Diligence in the Securities Litigation Reform Era: Practical Tips from Litigators on the Effective Conduct, Documentation and Defense of Underwriter Investigation, in CONDUCTING DUE DILIGENCE 2000, at 177, 207-08 (PLI Corp. Law \& Practice Course Handbook Series No. B-1176, 2000) (observing that on-line companies have a large portion of their value tied to intangible assets such as intellectual property); E. Lee Reichert, Mergers and Acquisitions in a Dot.com World, 29 CoLo. LAW. 37, 39 (2000) (observing that intellectual property constitutes large portions of the corporate assets of companies that conduct significant on-line business activities).

53. Privacy, 2 NO. E-COMMERCE L. REP. 33 (Glasser Legal Works 2000) ("For many dot[.]coms, one of their most valuable assets, if not their most valuable asset, is their customer database.'); see also Julia Alpert Gladstone, Data Mines and Battlefields: Looking at Financial Aggregators to Understand the Legal Boundaries and Ownership Rights in the Use of Personal Data, 19 J. MARSHALl J. COMPUTER \& INFO. L. 313, 329 (2001) ("The use of customer databases has become a critical strategy to successful business, and, thus, consumer profiles are a valuable intangible asset."); Marjorie Chertok \& Warren E. Agin, Restart.com: Identifying, Securing and Maximizing the Liquidation Value of Cyber-Assets in Bankruptcy Proceedings, 8 AM. BANKR. INST. L. REV. 255, 261-62 (2000) (observing that an "important asset of the Internet Company is information collected about customers and customer preferences"). Indeed, when an on-line company is heading toward bankruptcy, its most important assets are the domain name and customer information. See, e.g., Matt Marshall, Wine.com Fights for Survival, DETROIT FREE PRESS, Aug. 6, 2002 (reporting that during bankruptcy, the bankrupt estate consisted of the domain name and customer list, which were sold together for $\$ 3$ million), available at http://www.freep.com/features/food/wine6 20020806.htm.

54. See Gladstone, supra note 53, at 317-20 (discussing how technology such as HTML, OFX, and XML reduces the cost of collecting, maintaining, and manipulating consumer information). 
pages, ${ }^{5 s}$ application forms, order forms, surveys, contests, cookies, ${ }^{56}$ and Web bugs. ${ }^{57}$ The FTC reported in 2000 that about ninety-seven percent of all Internet sites and ninety-nine percent of the most popular Web sites collect information about visitors to their sites. ${ }^{58}$ Essentially, every Internet user in the United States is presently listed on between 25 to 100 databases. ${ }^{59}$

Customer information such as name, age, education, gender, email address, Uniform Resource Locater (URL), movements, and activities at every Web site a customer may visit can be collected. ${ }^{60}$

55. Delaney, supra note 42 , at 232 (noting that the majority of Web sites collects consumer data by requiring users to fill out registration forms); Richard S. Murphy, Property Rights in Personal Information: An Economic Defense of Privacy, 84 Geo. L.J. 2381, 2414 (1996) (observing how companies use on-line registration to collect valuable information). Specifically, on-line registration "is marketed to the consumer as beneficial for access to support services and product updates," but incidentally, "it provides the software merchant with valuable information about the consumer." Id.; see also Barbara Anthony, Federal Trade Commission Materials, in 1 CONSUMER FinANCIAL SERVICES LITIGATION 2001, at 731, 751-56 (PLI Corp. Law \& Practice Course Handbook Series No. B-1241, 2001) (attaching the FTC's June 2000 On-line Profiling: A Report to Congress, which illustrates how consumer information is collected at various points and how a consumer is profiled). A consumer's every activity on the Internet is tracked and analyzed to ascertain the consumer's tastes, needs, purchasing habits, and other interests and preferences. Id.

56. A cookie is a message given to a Web browser such as Microsoft Internet Explorer by a Web server. Cookie, WEBOPEDIA.COM, at http://webopedia.com/term/c/cookie/ html (last modified Feb. 19, 2003). The browser stores the message in a "cookie.txt" text file on an Internet user's computer hard drive. Id. When a user visits a Web site using cookies, the user may be asked to provide information such as name, email address, interests, and preferences. Id. The information is then stored in the cookie, sent to the user's Web browser and sits on the user's hard drive for later use. Id. When the user visits the same Web site in the future, the user's browser sends the cookie (with the stored information) to the Web server. Id. The Web server processes the information and presents the user with customized Web pages. Id. Essentially, the main purpose of cookies is to identify users and prepare customized Web pages for users in the near future. Id.

57. A Web bug is also called a "Web beacon" or a "clear GIF", a transparent graphic that is placed on a Web site or in an e-mail by a third party to monitor the behavior of a user visiting the Web site or sending the e-mail. Web beacon, WEBOPEDIA.COM, at http://www. webopedia.com/TERM/W/Web_beacon.html (last modified Aug. 21, 2003). Web bugs collect information such as IP addresses and URLs. On-line marketers use Web bugs to confirm shopping purchases, the effectiveness of an advertisement, etc.

58. Robert Pitofsky, Privacy On-line: Fair Information Practices in the Electronic Marketplace, Prepared Statement of the Federal Trade Commission Before the United States Senate Committee on Commerce, Science, and Transportation (May 25, 2000), at http://www.ftc.gov/os/2000/05/testimonyprivacy.htm.

59. Jeff Sovern, Opting In, Opting Out, or No Options at All: The Fight for Control of Personal Information, 74 WASH. L. REV. 1033, 1036 (1999).

60. See Federal Trade Comm'n, Online Profiling: A Report to Congress (2000), reprinted in Anthony, supra note 55, at 743-72 (describing what and how consumer information is collected and profiled); see also Acxiom Corp. Web Site (selling InfoBase Data Products, information of more than 176 million consumers that includes names, 
The raw, discrete factual information itself is not valuable. Consumer data becomes valuable when it is compared, contrasted, analyzed, and profiled to predict the consumer's interests, habits, desires, tastes, needs, and preferences. ${ }^{61}$ This enhanced consumer database essentially replaces the knowledgeable, personal sales person who assists the company in pushing the appropriate product and accurately reading the consumer in a store.

Internet companies use such enhanced consumer databases in their daily, intra-company marketing efforts, such as sending advertisements about the company's services and products to targeted consumers or implementing dynamic pricing. ${ }^{62}$ Some companies share the information with business partners. ${ }^{63}$ Others are in the database business, selling detailed consumer information to companies in need of such information for strategic marketing. ${ }^{64}$ The less fortunate, as bankrupts, liquidate their databases to satisfy obligations to creditors. ${ }^{65}$ Essentially, consumer databases, along with other intangibles such as intellectual property, are valuable assets held by Internet companies. ${ }^{66}$ This is a common characteristic shared by Internet companies that

addresses, e-mail addresses, lifestyles data, real-property ownership, and social and behavioral selectors), at http://www.acxiom.com (last visited Oct. 26, 2003).

61. See John M. Wingate, Comment, The New Economania: Consumer Privacy, Bankruptcy, and Venture Capital at Odds in the Internet Marketplace, 9 GEO. MASON L. REV. 895, 899-900 (2001) (discussing on-line profiling as practiced by DoubleClick.com, an online advertising and marketing company with a massive database of personalized information about users and their habits); Barrett, supra note 46, at 8-9 (discussing the marketing and advertising benefits to Internet companies from readily available consumer information).

62. Dynamic pricing entails "gauging a shopper's desire, measuring his means, and then charging accordingly. It supplies retailers with information that allows them to price goods according to customers' demographic and spending data." Jill Morneau, Dynamic Pricing: Who Really Wins?, CMP TECHWEB, Sept. 29, 2000, available at 2000 WL 2668566; see also Michael J. Martinez, Pricing Errors Hurting Amazon.com, AP OnLINE, Sept. 28, 2000 (explaining how Amazon.com collects consumer information and uses such information for dynamic pricing or price discrimination), available at 2000 WL 27212549.

63. Wingate, supra note 61, at 899-900 (explaining how DoubleClick.com cooperates with a large network of Web sites to track visitors' movements between sites and generate profiled information for advertising and marketing purposes).

64. Lori Liermann, Go Global. Get Information. Now What? All About the EU Directive and the U.S. Safe Harbor, Bus. L. TODAY, Jan.-Feb. 2003, at 57-60 (explaining how on-line companies are using and selling customer information); Susan E. Gindin, Lost and Found in Cyberspace: Informational Privacy in the Age of the Internet, 34 SAN DIEGo L. REV. 1153, 1162-63 (1997) (observing that there were more than 550 private companies in the information business with annual revenues in the billions).

65. E.g., Marshall, supra note 53 (reporting that the Wine.com brand and customer list were sold during bankruptcy to eVineyard).

66. See discussion infra Part III.C. 
often lack the traditional, tangible assets generally owned by brickand-mortar companies. ${ }^{67}$

Given the ease of collecting consumer information and the enormous value of consumer databases to on-line companies, consumer advocate groups have voiced their concerns on consumer privacy to governmental agencies. ${ }^{68}$ The FTC and consumer groups have sought injunctions in cases where on-line companies attempted to sell their consumer databases in violation of their stated privacy policies. ${ }^{69}$ As a result, some on-line companies have become more careful and more willing to address consumer privacy. ${ }^{70}$

\section{The Few Notable On-line Consumer Privacy Cases}

Because consumer information can be easily collected, aggregated, profiled, analyzed, and strategically used, Internet companies rely on consumer information for the survival and growth of their companies. ${ }^{71}$ Necessity dictates that on-line companies continue to collect and use consumer information. ${ }^{72}$ This necessity also forces on-line companies to avoid negative publicity or potential negative publicity relating to the aggregation and use of consumer information. $^{73}$

67. Andrew M. Kaufman, Counseling the Financially Distressed Technology Company: Finding and Preserving Value in E-Commerce Assets, in UNDERSTANDING EleCtronic Contracting: The Impact of Regulations, New laws \& NeW AgReEMENTS 69, 76-77 (PLI Intellectual Prop. Course Handbook Series No. G-697, 2002) (describing the different types of assets owned by old economy companies and new economy companies).

68. See Gindin, supra note 64 , at 1160-61 (noting that in response to the public outcry on privacy concerns, some database providers have eliminated sensitive information such as reverse telephone number searches, personal earnings and benefit estimate statements, and household information). See generally FEDERAL TRADE COMM'N, ONLINE Profiling: A RePORT to CONGRESS: PART 2, ReCOMmendations 9-11 (2000) (reporting to Congress the FTC's recommendations addressing on-line consumer privacy concerns), at http://www.ftc.gov/os/2000/07/onlineprofiling.pdf.

69. E.g., Trans Union Corp. v. FTC, 267 F.3d 1138 (D.C. Cir. 2001), cert. denied, 536 U.S. 915 (2002); FTC v. Toysmart.com, LLC, No. CIV. A. 00-CV11341RGS, 2000 WL 1523287, at *1 (D. Mass. Aug. 21, 2000); In re GeoCities, File No. 9823015, 1998 WL 473217 (FTC 1998).

70. Some companies, such as Yahoo, Lotus, and LEXIS-NEXIS, have changed their consumer information collection practices. See Gindin, supra note 64, at 1160-61. Others advocate new technology that allows consumers to have access to their data files, thus fostering trust in and loyalty to the Internet companies. Barrett, supra note 46, at 8-9.

71. Barrett, supra note 46 , at 9 (stating that consumer information reduces on-line companies' marketing and advertising spending, and that without such information some companies will not survive).

72. Id.

73. Id. 
On-line companies have addressed consumer privacy concerns by adopting a self-regulation approach. ${ }^{74}$ Under the self-regulation approach, an on-line company posts a privacy policy notice on its Web site and declares that the company is adhering to the policy. ${ }^{75}$ Many failed to observe their own privacy policy statements. ${ }^{76}$ A few made headlines and caught the public's attention.

For example, in July 2000 the FTC filed a complaint in a voluntary bankruptcy case against Toysmart.com for seeking to sell customer information in violation of the privacy notice posted by Toysmart.com on its Web site." Toysmart.com's privacy notice stated that personal information submitted by visitors to the site, such as name, address, billing information, and shopping preferences, "is never shared with a third party," and visitors "can rest assured that [their] information will never be shared with a third party." Pror to the involuntary bankruptcy petition filing date, Toysmart.com attempted to find buyers for its assets, including its customer database, by taking out an advertisement in the Wall Street Journal. ${ }^{79}$ Consumer groups and the FTC asserted that such a sale would violate the privacy policy posted by Toysmart.com on its site. ${ }^{80}$ Toysmart.com later settled

74. Marsha Cope Huie et al., The Right to Privacy in Personal Data: The EU Prods the U.S. and Controversy Continues, 9 TULSA J. COMP. \& INT'L L. 391, $394-96$ (2002) (tracing the self-regulation practiced by on-line companies and the evolution of the FTC's view toward self-regulation and federal regulation).

75. See Pitofsky, supra note 58 (stating that eighty-eight percent of a random sample of Web sites post a privacy disclosure). The survey revealed, however, that only twenty percent of such Web sites adopted the four fair information practice principles advocated by the FTC. Id.

76. Jane Kaufman Winn \& James R. Wrathall, Who Owns the Customer? The Emerging Law of Commercial Transactions in Electronic Customer Data, 56 Bus. LAw. 213, 233-34 (2000) (providing examples of how many on-line companies failed to adhere to their own privacy policy statements). Many companies apparently post their privacy policy statements without implementing adequate technological safeguards and procedures. Id.

77. Plaintiff's First Amended Complaint for Permanent Injunction and Other Equitable Relief at 9 17-18 [hereinafter FTC Complaint], FTC v. Toysmart.com, LLC, No. CIV. A. 00-CV11341RGS, 2000 WL 1523287 (D. Mass. Aug. 21, 2000), available at http://www.ftc.gov/os/2000/07/toysmartcomplaint.htm (last visited Sept. 27, 2003).

78. Id. $\uparrow 9$.

79. On May 22, 2000, Toysmart began soliciting bids for the purchase of its assets. Id. ๆ 11. Toysmart's creditors filed a petition for involuntary bankruptcy on June 9, 2000. Id. 712. Toysmart took out an advertisement in the Wall Street Journal on June 8, 2000. See Michael Brick, Judge Overturns Deal on Sale of On-line Customer Database, N.Y. TIMES, Aug. 18, 2000, at http://www.nytimes.com/library/tech/00/08/biztech/articles/18toys.html.

80. FTC Complaint, supra note 77, १ๆ 12-18; Richard A. Beckmann, Comment, Privacy Policies and Empty Promises: Closing the "Toysmart Loophole", 62 U. PITT. L. ReV. 765,765 (2001) (noting that the proposed sale of the consumer database by Toysmart was opposed by both the courts of law and public opinion as a violation of the privacy policy to which Toysmart promised to adhere). 
the matter with the FTC. ${ }^{81}$ Walt Disney Co., Toysmart.com's parent company, subsequently acquired the consumer database with the court's approval and destroyed the database. ${ }^{82}$

Similarly, despite the privacy policy DrKoop.com posted on its site, the company's treatment of its assets exposed many former customers of the health-portal site. ${ }^{83}$ While DrKoop.com was in bankruptcy, the trustee agreed not to approve transfers to third parties of customer information collected at the health portal site unless the consumers consented to the transfers. ${ }^{84}$ DrKoop.com later sold only the e-mail addresses of its registered users to Vitacost.com, but not other personal information, such as names, phone numbers, health information or purchase histories. ${ }^{85}$

The privacy violations by Toysmart.com and DrKoop.com became known and widely reported by the press because the companies publicly attempted to sell the consumer database while they were in bankruptcy. ${ }^{86}$ There are many privacy-violation cases, including collateralization of privacy, which occur without public knowledge, where Internet companies are not in bankruptcy

81. Press Release, Federal Trade Commission, FTC Announces Settlement with Bankrupt Website, Toysmart.com, Regarding Alleged Privacy Policy Violations (July 21, 2000), at http://www3.ftc.gov/opa/2000/07/toysmart2.htm.

82. See D. Ian Hopper, Settlement Reached in Toysmart Privacy Case, ConN. L. TRIB., Jan. 15, 2001, at 7 (noting the lack of a qualified buyer for the database; Disney, Toysmart's parent company, obtained the database and subsequently destroyed it).

83. Alorie Gilbert, Is (DrKoop) Taking Care of Privacy?, CNET NEWS.COM, July 1, 2002, available at http://zdnet.com.com/2100-1106-941028.html; John B. Kennedy \& Mary Wong, Recent Developments in U.S. Privacy Law, Including Post-September 11, 2001, in ThIRD ANNUAL InSTITUTE ON PRIVACy LaW: New DeVElopMENTS \& IsSUES IN a SeCURITY CONSCIOUS WORLD 11, 39-40 (PLI Intellectual Prop. Course Handbook Series No. G-701, 2002) (discussing recent cases relating to bankrupt on-line companies' sales of consumer information).

84. See Kennedy \& Wong, supra note 83, at 40; Press Release, Office of the Attorney General of the State of Texas, Attorney General Cornyn Gets Privacy Guarantees in Dr.Koop.com Bankruptcy (Mar. 19, 2002) [hereinafter Texas Attorney General Press Release], available at http://www.oag.state.tx.us/newspubs/releases/2002/20020319drkoop. htm.

85. Martina Brosnahan, Drkoop.com Purchased for $\$ 186,000$, E-SECURTIES, July 2002, at 6; Associated Press, Vitacost.com Acquires Dr.Koop.com for Cash (July 16, 2002), available at http://stopgettingsick.com/templates/news_template.cfm/6040.

86. See Brick, supra note 79; Failed Dot-Coms May Be Selling Your Private Information, July 1, 2000, available at http://www.nytimes.com/2000/07/01/technology/ 01 infor-selling.html; see also FTC v. Toysmart.com, LLC, No. CIV. A. 00-CV11341RGS, 2000 WL 1523287, at *1 (D. Mass. Aug. 21, 2000) (noting that Toysmart's creditors filed a petition for involuntary bankruptcy on June 9,2000 , and that the bankruptcy court allowed the petition on June 26, 2000); Texas Attorney General Press Release, supra note 84. 
proceedings or are not publicly attempting to sell their consumer database through advertisement in national newspapers. ${ }^{87}$

\section{E. Samples of Privacy Policy Statements}

A survey of privacy notices on a number of Web sites reveals that privacy statements are usually several pages long and available through a link displayed at the bottom of the homepage. ${ }^{88}$ Many privacy notices generally inform consumers that the company does not sell, share, or rent customer information to others. ${ }^{89}$ Additionally, companies such as eBay, Expedia.com, Monster.com, Microsoft.com, MSN.com, NASDAQ, Slate, Starbucks, uBid,Inc., and other companies, ${ }^{90}$ participate in Microsoft's .NET Passport Privacy Statement wherein the companies assert that they "will not sell or rent your personal information to third parties [and] will not use or share your personal information in a manner that differs from what is described in this Privacy Statement without your prior consent." Yahoo! Inc.'s privacy statement indicates that the company "does not rent, sell, or share personal information about you with other people or

87. The public was aware of the few known privacy cases where companies like Toysmart.com took out an advertisement in the Wall Street Journal. See Brick, supra note 79.

88. See, for example, homepages such as Yahoo! Inc., at http://www.yahoo.com; Amazon.com, Inc., at http://www.amazon.com; Travelocity.com LP, at http://www.travelocity. com; Microsoft Corporation, at http://www.microsoft.com; ABC, Inc., at http://www.abc. com; and VeriSign, Inc., at http://www.verisign.com.

89. See, e.g., Expedia Inc., Expedia.com's Privacy Pledge ("Expedia.com does not sell or rent your PII [personally identifiable information] to anyone."), at http://www. expedia.com/daily/service/privacy.asp (Dec. 12, 2002); Best Fares USA, Inc., Bestfares.com Privacy Policy ("Bestfares.com will not sell or lease Personal Information to third parties."), at http://www.bestfares.com/privacy.asp (last visited Sept. 27, 2003); RealNetworks, Inc., RealNetworks Privacy Policy ("RealNetworks does not sell, rent, or share your personal information to a third party, unless you specifically consent to provide such information to a third party partner or content service."), at http://www.realnetworks.com/company/privacy/? $\mathrm{src}=121202$ realhome_2_1.htm (last updated May 20, 2003).

90. Microsoft.NET Passport, Directory of Sites, at http://www.passport.net/ Directory/Default.asp?PPDir=C\&lc=1033 (last visited Sept. 27, 2003).

Other companies include ActiveState, CallServe, Citicards.com, ComponentSource, Corbis Corporation, Devhood, FastAccess, SA, fboweb.com, fye.com, GotDotNet, Groove Networks, Hostbasket.com, Informatica Para Profesionales S.A., Lastminute.com, McAfee.com, Omni Domain, Powermingle, pressplay, PrimaryDotNet, QXL, RadioShack Canada, Reynolds \& Reynolds, Self Surveys, Singapore Exchange, Sofhar, Speedle, SuperOffice, Surveys.com, Triathlon Australia, ValetNoir, vbCentral.net, Webdrive.ru, WebHealthCentre.com, WorldofShopping.com, Xdrive Technologies, YouKnowBest, and Young Scot Enterprises. Id.

91. Microsoft.NET Passport, Privacy Statement, at http://www.passport.net/ Consumer/PrivacyPolicy.asp?lc=1033 (last updated May 2003). 
nonaffiliated companies." ${ }^{.92}$ Travelocity.com LP also states that it does "not sell individual customer names or other private profile information to third parties and [has] no intention of doing so in the future." Hotwire promises "never to sell or rent any of your personal information without your prior consent.".94

Internet companies, including the above mentioned, probably believe that as long as they are not selling, leasing, or sharing the consumer information to a third party, they are in compliance with their own privacy statements. Whether intentional or unintentional, many Internet companies ignore their own privacy policy statements when the companies pledge their customer database as collateral in secured financing schemes. This practice renders on-line privacy statements misleading because the statements are silent on collateralization of the company's assets.

\section{The COllateralization SCHEME}

\section{A. Examples of Collateralization}

Every day, countless secured finance transactions occur and examples of collateralization abound. ${ }^{95}$ A company that is in need of capital may obtain a term loan from an institutional lender. ${ }^{96}$ The lender may be less sanguine about the company's ability to pay back

92. Yahoo! Inc., Yahoo! Privacy Policy, at http://privacy.yahoo.com/privacy/us/my (last visited Sept. 27, 2003).

93. Travelocity.com LP, Privacy Policy, at http://www.travelocity.com (last visited Oct. 22, 2003).

94. Hotwire.com, Privacy Policy, at http://www.hotwire.com/travel-information/ privacy-policy.jsp?lid=index.jsp=bnav:loc:0:privacy (last visited Oct. 3, 2003).

95. Lucian Arye Bebchuk \& Jesse M. Fried, The Uneasy Case for the Priority of Secured Claims in Bankruptcy, 105 YALE L.J. 857, 860 (1996). The Federal Reserve provides statistical information on small and large secured loans made to businesses by commercial banks: $83.1 \%$ of loans of less than $\$ 100,000$ are secured; $69.7 \%$ of loans between $\$ 100,000$ and $\$ 999,000$ are secured; $42.5 \%$ of loans between $\$ 1,000,000$ and $\$ 9,999,000$ are secured; and only $34.6 \%$ of loans over $\$ 10,000,000$ are secured. FED. RESERVE BD., FEDERAL ReSERVE Statistical Release: SuRVEy of Terms of Business Lending, NOVEMBER 6-10, 2000, tbl.1 (2000), available at http://www.federalreserve.gov/releases/e2/200011/e2.pdf.

96. See Evan H. Krinick \& Celeste M. Butera, Lenders Must Take Care When Perfecting a Lien on a Borrower's Patents and Copyrights, 117 BANKING L.J. 49, $49-50$ (2000) (referring to banks making loans to startup companies and taking liens on these companies' intellectual property assets); Scott J. Driza, Perfecting Security Interests in Intellectual Property, 88 ILL. B.J. 162, 162 (2000) (discussing how companies increasingly use their intellectual property as collateral when borrowing capital from banks); see also Cong. Fin. Corp. v. John Morrell \& Co., 790 F. Supp. 459, 461 (S.D.N.Y. 1992) (describing a lender's term loan to a company); Info. Exch. Sys., Inc. v. First Bank Nat'l Ass'n, Nos. CIV. 491-902, CIV. 4-92-224, 1992 WL 494607, at *1 (D. Minn. July 23, 1992) (describing a lender's term loan to a debtor), aff'd, 994 F.2d 478 (8th Cir. 1993). 
the loan and request that the company secure the debt by offering some or all of the company's present and future assets, such as equipment, machinery, inventory, accounts receivable, patents, trademarks, and other personal property. ${ }^{97}$ The assets used to secure the company's payment of the loan are called the collateral. ${ }^{98}$ The company is the debtor, and the transaction between the debtor and the lender is a secured transaction typically governed by article 9 of the Uniform Commercial Code. ${ }^{99}$

In some instances, instead of a term loan, the debtor and the lender may negotiate a revolving credit line wherein the lender takes a security interest in the company's assets and expects periodic payments from the company. ${ }^{100}$ The debtor and the lender may agree on a formula which factors in the company's collateral assets in determining the amount of the credit line..$^{101}$

Instead of taking a loan, the debtor can obtain on credit inventory for its retail operations in a financing transaction wherein the financier

97. See, e.g., Cong. Fin. Corp., 790 F. Supp. at 461 (lender's term loan was secured by equipment, machinery, real estate, patents, and trademarks); Info. Exch. Sys., Inc., 1992 WL 494607 , at *1 (stating that the lender's term loan was secured by a blanket security interest in the debtor's assets).

98. U.C.C. § 9-102(12) (2003) (defining collateral as "property subject to a security interest or agricultural lien").

99. Id. §9-102(28)(A) (stating that a debtor means "a person having an interest ... in the collateral, whether or not the person is an obligor"). An obligor means "a person that, with respect to an obligation secured by a security interest in ... the collateral, (i) owes payment or other performance of the obligation." Id. §9-102(59). Article 9 defines a secured transaction as "a transaction, regardless of its form, that creates a security interest in personal property or fixtures by contract." Id. § 9-109(a)(1). A security interest means "an interest in personal property ... which secures payment or performance of an obligation." U.C.C. § 1-201(35) (2003).

100. See Ingrid Michelsen Hillinger et al., Deposit Accounts Under the New World Order, 6 N.C. BANKING INST. 1, 47 (2002) (providing a basic example of secured financing wherein the bank lends money to the debtor and the debtor grants the bank a blanket security interest in inventory and equipment to secure repayment of the loan); see also Cong. Fin. Corp., 790 F. Supp. at 461 (revolving credit loans secured by a debtor's accounts receivable, inventory, work in progress, supplies, and other miscellaneous assets); Info. Exch. Sys., Inc., 1992 WL 494607, at *1 (revolving credit loans secured by a debtor's blanket security interest in its assets, including all intellectual property).

101. For example, in Congress Financial Corp. v. John Morrell \& Co., the lender calculated that the credit line was based on eighty-five percent of the debtor's eligible accounts receivable, sixty-five percent of the debtor's eligible product inventory, and thirty percent of the debtor's eligible supplies. $790 \mathrm{~F}$. Supp. at 461 . The debtor provided a daily report of its accounts receivable, product inventory, and supplies. Id. Because these numbers changed daily, the debtor's financing eligibility varied from day to day. Id. 
is the supplier. ${ }^{102}$ The debtor promises to make regular payments on the inventory and grants the supplier a security interest in the inventory. ${ }^{103}$

The above transactions are common in everyday business affairs. In each of the financing transactions, the company uses its corporate assets as collateral. ${ }^{104}$ These illustrations are rudimentary examples of secured transactions. ${ }^{105}$ As changes in technology have facilitated expansion of the range of the debtor's available assets which can be used as collateral, secured transactions have become the "linchpin of private financing, prompting even large firms to employ leveraged buyouts as a means of fleeing public equity markets for the safe harbors of Article 9."'106

\section{B. Article 9 of the Uniform Commercial Code}

Prior to the promulgation and adoption of article 9 of the Uniform Commercial Code, secured transactions were subject to a wide range of state laws. ${ }^{107}$ Article 9 has been widely adopted by states

102. See generally James E. Britton, Consignments, Landlord's Lien, Purchase Money Security Interest and Rights of Transferees of Collateral, 25 OKLA. CITY U. L. REV. 213, 22426 (2000) (explaining the arrangement between the inventory debtor and the vendor wherein the vendor provides inventory on credit to the debtor and takes a purchase money security interest in the inventory); Richard M. Cieri et al., Considerations for Chapter 11 Retail Debtors, 6 J. BANKR. L. \& PRAC. 451, 464 (1997) (observing that "[i]n certain retail Chapter 11 cases, particularly when the debtor has found it too difficult or too costly to obtain DIP [debtor-in-possession] financing, the debtor may nonetheless be able to obtain inventory financing from its vendors").

103. See Britton, supra note 102, at 225 (discussing purchase money security interests obtained by inventory vendors).

104. Claire A. Hill, Is Secured Debt Efficient?, 80 TEX. L. REv. 1117, 1124-27 (2002) (explaining different features of secured lending).

105. See id. (discussing different transactions in the real world based on a typical example of secured financing).

106. Robert E. Scott, The Politics of Article 9, 80 VA. L. REV. 1783, 1785 (1994). Dean Scott also noted that a survey of about 500,000 small firms had shown that sixty-two percent of the respondents' debt was secured for the years in question. Id. at $1785 \mathrm{n} .1$ (citing Alan Schwartz \& Robert E. SCOTt, Commercial Transactions: Principles and POLICIES 547 (2d ed. 1991)).

A more sophisticated secured transaction may include a leveraged buyout company (LBC) that decides to take over Company $A$ (the "purchase" phase). The LBC then uses Company $A$ 's assets as collateral to finance the purchase of Company $A$ (the "financing" phase). Marilee C. Unruh, Introduction to For-Profit Mergers \& Acquisitions, in HEALTH CARE M\&A: COMMERCIALIZATION OF THE MEDICAL INDUSTRY 29, 38-39 (PLI Commercial Law \& Practice Course Handbook Series No. A-741, 1996) (discussing the basic elements of mergers and acquisitions among for-profit entities).

107. See generally Lois R. Lupica, Circumvention of the Bankruptcy Process: The Statutory Institutionalization of Securitization, 33 CONN. L. REV. 199, 202-04 (2000) (discussing pre-article 9 state laws governing various forms of secured transactions and how such a system yielded inefficiency and unpredictability); Grant Gilmore, The Good Faith Purchase Idea and the Uniform Commercial Code: Confessions of a Repentant Draftsman, 
and governs transactions involving collateral that consists of personal property and fixtures which serve as security for satisfaction of a payment or obligation. ${ }^{108}$ Article 9 was revised in 1999 and became effective as of July 1, 2001 in all fifty states, and the District of Columbia. ${ }^{109}$ The new article 9 contained significant changes in scope, incorporating new property and transactions that were excluded under the 1972 version of article 9, and "simplifying and clarifying the rules for creation, perfection, priority, and enforcement of a security interest." ${ }^{\prime 10}$ All revisions were intended to provide greater certainty to secured financing transactions and reduce both transaction costs and the cost of credit. ${ }^{111}$

Under article 9, personal property that is collateralized in a secured financing transaction falls into different classifications and sub-classifications. ${ }^{112}$ Such a detailed classification system is necessary because different types of collateral assets require different methods of perfection of the security interest in that asset. Moreover,

15 GA. L. REV. 605, 620 (1981) (characterizing pre-article 9 security law as obscure); see also U.C.C. § 9-101 cmt. (1972) (chronicling the history of article 9's development). The 1972 version of the official comment to section 9-101 states:

The growing complexity of financing transactions forced legislatures to keep piling new statutory provisions on top of our inadequate and already sufficiently complicated nineteenth-century structure of security law. The results of this continuing development were increasing costs to both parties and increasing uncertainty as to their rights and the rights of third parties dealing with them.

The aim of this Article is to provide a simple and unified structure within which the immense variety of present-day secured financing transactions can go forward with less cost and with greater certainty.

U.C.C. $\S 9-101 \mathrm{cmt}$.

108. See Henry Gabriel, Louisiana Chapter Nine (Part One): Creating and Perfecting the Security Interest, 35 LoY. L. REV. 311, 312 (1989) ("Article Nine of the [U.C.C.] provides for a simple, uniform security device for movable corporeal and incorporeal property which is designed to replace the myriad of pre-code security devices."). Professor Gabriel observed that Louisiana was the last state to adopt the 1972 version of article 9 and that article 9 became effective on July 1, 1989. Id.; see also Scott, supra note 106, at 1791-93 (observing the benefits of article 9, which include controlling the self-interested debtor's incentive to lie about the existence of prior liens, curbing the debtor's misbehavior, and increasing the efficiency of secured credit).

109. Uniform Law Commissioners, A Few Facts About the Revised UCC Article 9, Secured Transactions (1999), at http://www.nccusl.org/nccusl/uniformact_factsheets/ uniformacts-fs-ucca9.asp (last visited Oct. 3, 2003).

110. See Steven O. Weise, An Overview of Revised UCC Article 9, in THE New ARTICle 9 UNIFORM COMMERCIAL CODE 1, 1 (Corinne Cooper ed., 1999).

111. Id.

112. Robert J. Bein, A Horse of a Different Color: Problems of Classification Under Article 9 of the UCC, AM. BANKR. INST. J. July-Aug. 2002, at 22 (explaining how a horse may be classified as a farm product, consumer good, inventory, or equipment under article 9). 
priority rules depend on how perfection occurs. ${ }^{113}$ Perfection is a process through which the creditor establishes its rights in the collateral against the rest of the world. ${ }^{114}$ It is crucial for a creditor to understand how the debtor's assets used as collateral are classified under article 9 so the creditor can apply the appropriate method of perfection to achieve a priority right in the collateral."

Generally, personal property used as collateral falls into three different groups: tangibles, quasi-tangibles and intangibles. ${ }^{116}$ Tangible collateral includes consumer goods, ${ }^{117}$ inventory, ${ }^{118}$ farm products, ${ }^{119}$

113. Steven O. Weise, U.C.C. Survey-Article 9 Developments, 57 Bus. LaW. 1751, 1757 (2002) ("The proper classification of collateral has important consequences for purposes of adequately describing the collateral, determining in some circumstances the jurisdiction of perfection, determining the method of perfection, and resolving priority disputes." (footnotes omitted)); Bein, supra note 112, at 22 ("Classification of collateral is critical to questions of perfection and priority under Article 9 of the Uniform Commercial Code ...."); see also U.C.C. $\$ 9-309$ (2003) (listing the types of security interests that can be perfected by attachment); id. $\S 9-310$ (requiring the filing of a financing statement as the most common method for perfecting security interests for the majority of collateral property, but noting exceptions); id. $\S 9-313$ (permitting a secured party to perfect certain security interests by taking possession of collateral property); id. $\S 9-314$ (providing for the perfection of the security interest by obtaining control of investment property, deposit accounts, letter of credit rights, and electronic chattel paper).

114. Philip H. Ebling \& Steven O. Weise, What a Dirt Lawyer Needs to Know About New Article 9 of the UCC, 37 Real Prop. Prob. \& TR. J. 191, 197 n.22 (2002) (defining perfection as "the status that generally puts third parties ... on notice of the security interest and gives the secured party protection against claims of lien creditors"); Shawn K. Baldwin, Comment, "To Promote the Progress of Science and Useful Arts": A Role for Federal Regulation of Intellectual Property as Collateral, 143 U. PA. L. REv. 1701, 1702 n.5 (1995) (defining perfection as "the process by which a secured party's security interest in a debtor's collateral is protected against competing claims to the collateral by third parties").

115. Douglas G. Baird, The Importance of Priority, 82 CoRNELL L. REv. 1420, 1423 (1997) (noting that establishing priority is one way for creditors to organize themselves in the event of debtor's default); Ebling \& Weise, supra note 114, at 197 n.22 (noting that priority is "the ranking of competing interests in property" and that the ranking is based on a number of factors, including whether a security interest has attached and perfected, when the perfection occurred, and how the perfection was achieved).

116. See U.C.C. §9-102(a)(44) (2003) (stating that goods "means all things that are movable when a security interest attaches"). Goods are tangible property. Quasi-tangibles are property that are in the form of pieces of paper, such as investment property, warehouse receipts, chattel papers, and instruments. See id. §9-102(a)(44). Intangibles are property that have no significant physical form, such as accounts, deposit accounts, general intangibles, etc. See id. § 9-102(a)(44).

117. Id. §9-102(a)(23) (stating that consumer goods "means goods that are used or bought for use primarily for personal, family, or household purposes").

118. Id. §9-102(a)(48) (stating that inventory means goods which are leased, held for sale or lease, furnished under a contract of service, raw materials, or materials used or consumed in a business).

119. Id. §9-102(a)(34) (defining farm products as crops, aquatic goods, livestock, "supplies used or produced in a farming operation," or "products of crops or livestock in their unmanufactured states"). 
and equipment. ${ }^{120}$ Quasi-tangibles are documents, ${ }^{121}$ such as warehouse receipts and bills of lading, ${ }^{122}$ chattel papers, ${ }^{123}$ instruments, ${ }^{124}$ including promissory notes, ${ }^{125}$ and investment properties like stocks and bonds. ${ }^{126}$ Intangibles are accounts, ${ }^{127}$ deposit accounts, ${ }^{128}$ health-care-insurance receivables, ${ }^{129}$ and general intangibles. ${ }^{130}$

\section{Consumer Databases as Collateral}

As a consequence of the profound changes in technology in recent years, more companies own intellectual property such as patents, trade secrets, copyrights, trademarks, domain names, and consumer databases. ${ }^{131}$ On-line companies, owing to the nature of the

120. Id. $\S 9-102(\mathrm{a})(33)$ (stating that equipment is the catch-all category for goods that are not consumer goods, inventory, or farm products).

121. Id. §9-102(a)(30) (stating that a document "means a document of title or a receipt of the type described in Section 7-201(2)"). Section 7-201(2) indicates the warehouse receipt. U.C.C. § 7-201(2) (2003).

122. U.C.C. $\S 1-201(6)$ (2003) (stating that a bill of lading means "a document evidencing the receipt of goods for shipment issued by a person engaged in the business of transporting or forwarding goods").

123. U.C.C. §9-102(a)(11) (defining chattel paper as a "record or records that evidence both a monetary obligation and a security interest in specific goods"). Monetary obligation means an obligation "secured by the goods or owed under a lease of the goods and includes a monetary obligation with respect to software used in the goods." Id. §9102(a)(11).

124. Id. §9-102(a)(47) (stating that an instrument is "a negotiable instrument or any other writing that evidences a right to the payment of a monetary obligation").

125. Id. $\S 9-102(\mathrm{a})(65)$ (a promissory note is "an instrument that evidences a promise to pay a monetary obligation, does not evidence an order to pay, and does not contain an acknowledgment by a bank that the bank has received for deposit a sum of money or funds").

126. Id. § 9-102(a)(49) (an investment property means "a security, whether certificated or uncertificated, security entitlement, securities account, commodity contract, or commodity account").

127. Id. §9-102(a)(2) (stating that an account means "a right to payment of a monetary obligation, whether or not earned by performance").

128. Id. §9-102(a)(29) (explaining that a deposit account is a "demand, time, savings, passbook, or similar account maintained with a bank").

129. Id. $\S 9-102(\mathrm{a})(46)$ (defining a health-care-insurance receivable as "an interest in or claim under a policy of insurance which is a right to payment of a monetary obligation for health-care goods or services provided or to be provided").

130. Id. $\S 9-102(a)(42)$ (explaining that a general intangible is a catch-all term for "any personal property, including things in action, other than accounts, chattel paper, commercial tort claims, deposit accounts, documents, goods, instruments, investment property, letter-ofcredit rights, letters of credit, money, and oil, gas, or other minerals before extraction. The term includes payment intangibles and software").

131. Kaufman, supra note 67 , at 89 (noting that an on-line company's asset base consists primarily of trademarks, patents, copyrights, contracts, domain names, and customer lists); see generally Alice Haemmerli, Insecurity Interests: Where Intellectual Property and Commercial Law Collide, 96 ColuM. L. Rev. 1645, 1651-52 (1996) (explaining that the economic significance of intellectual property is attributable to the deregulation of the 
global, electronic medium of Internet commerce, often only have valuable assets in the form of intangibles. When in need of capital, these companies must turn to these intangible assets, including consumer databases, to serve as collateral in secured transactions. ${ }^{132}$ Indeed, investors and creditors, particularly in the post-dot-com bubble economy, have realized that equity financing has lost its luster and have resorted to traditional financing schemes or secured transactions to protect their interest. ${ }^{133}$ The question then arises as to how the security interest in a consumer database is perfected.

The use of intangible assets, such as the various forms of intellectual property, as collateral in secured financing schemes is not new, but has become increasingly common in recent years. ${ }^{134}$ Article 9 , and, in some instances, specific federal statutes, govern the perfection of security interests in intellectual property assets. ${ }^{135}$

Under article 9, there is no specific classification for the various forms of intellectual property, such as copyrights, patents, trademarks, trade dress, and trade secrets, that serve as collateral. Instead, intellectual property is included in the catch-all "general intangibles" classification. ${ }^{136}$

telecommunications industry and the growth of the Internet); Baldwin, supra note 114, at 1704-05 (stating that a company's intellectual property assets are now more valuable than its real property and become the dominant factor in commercial transactions).

132. See Kaufman, supra note 67, at 95 (advising how to protect the investor's interest in on-line companies through an understanding of the nature of the assets and the appropriate methods of preserving the on-line companies' assets in secured transactions).

133. Id.

134. The use of intellectual property as collateral in secured financing is more than a century old. See Baldwin, supra note 114 , at 1701 (noting that in the late 1880 s, Thomas Edison used his famous patent for the incandescent electric light as collateral to secure the loan he borrowed to start his company, which later became General Electric Company). In today's economy, lenders often find that when a company is asking for financing, it usually has its most valuable assets in intangibles. Id. at 1704-06 (explaining why intellectual property assets have increasingly become recognized as valuable assets in financing transactions); see, e.g., Krinick \& Butera, supra note 96, at 49-50 (addressing what banks should be aware of when they take a security interest in various forms of intellectual property assets); Driza, supra note 96, at 162 (stating that when start-up companies seek capital, secured lenders often discover that the company's intellectual property is the only valuable collateral). For a comprehensive review of the evolution of intellectual property financing, see Lorin Brennan, Financing Intellectual Property under Federal Law: A National Imperative, 23 HASTINGS COMM. \& ENT. L.J. 195, 209-99 (2001).

135. See Baldwin, supra note 114, at 1702.

136. See Thomas M. Ward, The Perfection and Priority Rules for Security Interests in Copyrights, Patents, and Trademarks: The Current Structural Dissonance and Proposed Legislative Cures, 53 ME. L. REv. 391, 397 (2001) (stating that various principal forms of intellectual property are "general intangibles" under article 9); U.C.C. \$ 9-102 cmt. 5(d) (2003) (explaining that general intangibles serve as a residual category of personal property). Comment 5(d) states that 
A consumer database may be protected under trade secret or copyright law. Under trade secret law, the consumer database is entitled to trade secret protection if the consumer database is not publicly available information and is kept in secrecy. ${ }^{137}$ Courts have routinely held that customer databases, ${ }^{138}$ customer lists, and detailed information are trade secrets. ${ }^{139}$ Trade secret protection, however, may not be available for consumer databases because their owners must engage in mass-market distribution, which involves the disclosure of the consumer database. Such distribution will destroy the secrecy requirement. ${ }^{140}$

Copyright law protects works that are original and fixed in a tangible medium. ${ }^{141}$ Under copyright law, the consumer information

"[g]eneral intangible" is the residual category of personal property, including things in action, that is not included in the other defined types of collateral. Examples are various categories of intellectual property .... As used in the definition of "general intangible," "things in action" includes rights that arise under a license of intellectual property, including the right to exploit the intellectual property without liability for infringement.

Id. $\S 9-102 \mathrm{cmt}$. 5(d).

137. See Ed Nowogroski Ins., Inc. v. Rucker, 971 P.2d 936, 944 (Wash. 1999) (en banc) (analyzing the requirements for protection of the customer list and associated information under the common law and under the Uniform Trade Secrets Act).

138. MAI Sys. Corp. v. Peak Computer, Inc., 991 F.2d 511, 521 (9th Cir. 1993) (holding that misappropriation of trade secrets occurs "if information from a customer database is used to solicit customers").

139. See, e.g., NewSouth Communications Corp. v. Universal Tel. Co., No. CIV. A. 02-2722, 2002 WL 31246558, at *15-*20 (E.D. La. Oct. 4, 2002) (holding that customer names, correspondence, collection, and accounts are trade secrets, and that the defendant misappropriated them); Merrill Lynch, Pierce, Fenner \& Smith, Inc. v. Chung, No. CV0100659 CBM RCX, 2001 WL 283083, at *3-*4 (C.D. Cal. Feb. 2, 2001) (finding Merrill Lynch's customer lists were entitled to trade secret protection); BioCORE, Inc. V. Khosrowshahi, 96 F. Supp. 2d 1221, 1235 (D. Kan. 2000) (noting that detailed customer records such as "purchasing patterns, sales volumes and payment histories may be a trade secret"); Avery Dennison Corp. v. Kitsonas, 118 F. Supp. 2d 848, 854 (S.D. Ohio 2000) (holding that a customer list is a trade secret under state law, as is "business information or plans, financial information or listing of names, addresses, or telephone numbers" (citation omitted)); Morlife, Inc. v. Perry, 66 Cal. Rptr. 2d 731, 735-37 (Ct. App. 1997) (holding that customer lists are protected under trade secret law); Courtesy Temp. Serv. v. Camacho, 272 Cal. Rptr. 352, 357 (Ct. App. 1990) (holding that customer lists are entitled to trade secret protection).

140. See Winn \& Wrathall, supra note 76, at 244 (analyzing how trade secret protection is not available to databases subject to mass-market distribution).

141. 17 U.S.C. $\S 102$ (a) (2000) (stating that "[c]opyright protection subsists ... in original works of authorship fixed in any tangible medium of expression"); see also Jane C. Ginsburg, No "Sweat"? Copyright and Other Protection of Works of Information After Feist v. Rural Telephone, 92 COLUM. L. REv. 338, 343-48 (1992) (analyzing the originality requirement imposed by Feist Publications, Inc. v. Rural Telephone Service Co., 499 U.S. 340 (1991), and assessing how such a new rule will lead to increased costs and inefficiency). 
itself is not protected. ${ }^{142}$ The arrangement of the database is entitled to copyright protection only if the arrangement is original and fixed in a tangible medium..$^{143}$ The copyright protection, even for an original arrangement, is weak. ${ }^{144}$ Most commentators believe that there is no copyright protection for consumer databases. ${ }^{145}$

If a consumer database is entitled to copyright protection and is registered by the Copyright Office, perfection of the database occurs under the federal regime, not article 9. ${ }^{146}$ Perfection in the registered, copyrighted consumer database occurs when a record of the security interest in the consumer database is filed with the Copyright Office. ${ }^{147}$ If a consumer database is not protected under copyright law and not registered by the Copyright Office, the security interest in the consumer database is perfected by filing a financing statement with the Office of the Secretary of State. ${ }^{148}$ The same method of perfection

142. Feist, 499 U.S. at 350-51. The United States Supreme Court in Feist held that [f]acts, whether alone or as part of a compilation, are not original and therefore may not be copyrighted. A factual compilation is eligible for copyright if it features an original selection or arrangement of facts, but the copyright is limited to the particular selection or arrangement. In no event may copyright extend to the facts themselves.

Id.

143. Id. at $349-57$.

144. Id. at 349 ("[T] compiler remains free to use the facts contained in another's publication to aid in preparing a competing work, so long as the competing work does not feature the same selection and arrangement.").

145. Jonathan C. Lipson, Financing Information Technologies: Fairness and Function, 2001 WIS. L. REV. 1067, 1081-82 (stating that databases are generally not subject to copyright protection in light of the Feist decision); Winn \& Wrathall, supra note 76, at 238-40 (analyzing the limitations of copyright protection for databases and noting that a recent decision allows competitors to copy databases without violating copyright law); Jane C. Ginsburg, Copyright, Common Law, and Sui Generis Protection of Databases in the United States and Abroad, 66 U. CIN. L. REV. 151, 157 (1997) (observing that the limited copyright protection for databases has lent itself to alternative protection under state law).

146. In re World Auxiliary Power Co., 244 B.R. 149, 151-59 (Bankr. N.D. Cal. 1999) (analyzing prior case authority on perfection of security interests in registered copyrights and holding that the federal perfection regime is applicable to registered copyrights, while state law U.C.C. article 9 is applicable to unregistered copyrights), aff'd, 303 F.3d 1120 (9th Cir. 2002).

147. Justin M. Vogel, Note, Perfecting Security Interest in Unregistered Copyrights: Preemption of the Federal Copyright Act and How Filing in Accordance with Article 9 Leads to the Creation of a Bankruptcy "Force Play", 10 AM. BANKR. INST. L. REV. 463, 464-65 (2002) (reviewing cases on perfection of security interests in unregistered and registered copyrights and suggesting that perfection of copyrights, regardless of registration status, should be recorded in the Copyright Office).

148. William Murphy, Proposal for a Centralized and Integrated Registry for Security Interests in Intellectual Property, 41 IDEA 297, $331-32$ n.112 (2002) (noting that case law 
is applied if the consumer database is protected under trade secret law. ${ }^{149}$

Peculiarly, regardless of whether a consumer database may be protected under trade secret or copyright law or neither, when a consumer database is used as collateral in secured financing transactions, it is classified as a general intangible. ${ }^{150}$ Under article 9, a consumer database is deemed personal property and can be used as collateral in secured financing transactions. ${ }^{151}$ If a consumer database is protected under neither copyright nor trade secret law, ${ }^{152}$ the consumer database is still personal property of the debtor, and perfection of the security interest in the database is completed by filing the financing statement with the Office of the Secretary of State. ${ }^{153}$

demonstrates that the most effective method to protect a security interest in unregistered copyrights is under the U.C.C. article 9 regime).

149. See generally In re Levitz Ins. Agency, Inc., 152 B.R. 693, 697 (Bankr. D. Mass. 1992) (holding that a filed financing statement that contained a description of a customer list was sufficient for perfection of a security interest in the customer list); In Re Roman Cleanser Co., 802 F.2d 207, 212-13 (6th Cir. 1986) (Thomas, J., concurring) (concluding that a security interest in a customer list was properly perfected under an article 9 filing).

150. Kaufman, supra note 67 , at 93 (stating that a consumer database is classified as a "general intangible"); Jonathan C. Lipson, Remote Control: Revised Article 9 and the Negotiability of Information, 63 OHIO ST. L.J. 1327, 1343 (2002) (stating that "general intangibles" include consumer databases).

151. See, e.g., Levitz Ins. Agency, 152 B.R. at 697 (customer list classified as a general intangible); In re Emergency Beacon Corp., 23 U.C.C. Rep. Serv. (CBC) 766, 769 (Bankr. S.D.N.Y. 1977) ("[C]ustomer lists, books and records ... are general intangibles."); Susan Barbieri Montgomery, Security Interests in Intellectual Property, SG085 ALI-ABA 385 (2002) (customer lists are general intangibles); Larren M. Nashelsky \& Douglas McPherson, Restructuring and Bankruptcy Alternatives for the New Economy Company, in AdVANCEd DoING Deals 2001: MaximizING Old \& New ECONOMY DEALS, 251, 262 (PLI Corp. Law \& Practice Course Handbook Series No. B-1259, 2001) (customer lists are general intangibles); Dan L. Nicewander, General Intangibles Under Revised Article 9, 54 CONSUMER FIN. L.Q. REP. 169, 169-70 (2000) (general intangibles include "customer lists and files, trade names, newsletters, liquor licenses," and intellectual property).

152. In re Avalon Software, Inc., 209 B.R. 517, 519-22 (Bankr. D. Ariz. 1997). On the other hand, if a consumer database is protected under both copyright and trade secret regimes, perfection of the security interest in the copyrighted consumer database must be filed with the Copyright Office, regardless of whether the consumer database is a trade secret. Id.

153. See Kaufman, supra note 67 , at 95 (advising that the perfection of a security interest in consumer data, a general intangible, is best achieved by filing the financing statement); see also U.C.C. $\$ 9-307 \mathrm{cmt} .2$ (2003) (stating that the location of the debtor determines the jurisdiction whose law governs perfection and priority of a security interest in general intangibles); Id. $\S 9-307 \mathrm{cmt} .3$, ex. 1 (where the general intangibles are accounts and the debtor is an English corporation with offices in both the United States and London, England, perfection of the security interest occurs by filing the financing statement with the District of Columbia because the foreign debtor is deemed to be located in that district). 
Indeed, many companies have collateralized their consumer databases. $^{154}$ Consumer databases are important assets that are compiled, maintained, and analyzed by companies to enhance the operation of their businesses and their dealings with strategic partners. ${ }^{155}$ Companies spend significant resources to collect customer information, maintain the information in computer databases, ${ }^{156}$ and prevent others from unauthorized mining. ${ }^{157}$

\section{ThE PERVASIVE VIOLATION OF PRIVACY}

\section{A. The Security Agreement}

In a secured finance transaction, the security agreement is the contractual document binding the debtor and creditor to its terms. ${ }^{158}$ In order for the collateralization process to occur, the security interest in the collateral must have attached. ${ }^{159}$

154. Walter W. Miller, Jr. \& Maureen A. O'Rourke, Bankruptcy Law v. Privacy Rights. Which Holds the Trump Card?, 38 Hous. L. Rev. 777, 788 (2001) (noting that many companies use customer lists and associated information as collateral in secured transactions).

155. Id. at 783-84 (recognizing how consumer information is aggregated, manipulated, and transferred, and how enhanced consumer information has become even more valuable in today's market as it helps advertisers and sellers target consumers more effectively); see also Privacy, supra note 53, at 33 (reporting that the customer database is the most valuable asset owned by on-line companies); Chertok \& Agin, supra note 53, at 262 (stating that information collected about customers and their preferences is an important corporate asset of a typical Internet company).

156. See Privacy, supra note 53, at 33 (reporting that companies spent millions of dollars to develop customer databases, and that some companies had paid $\$ 40-\$ 100$ for data per customer); Gladstone, supra note 53, at 313 (discussing how XML technology eases the cost of collection, aggregation, storage, and manipulation of consumer data).

157. For example, eBay owns a vast computer database, controls access to the database, and vigorously enforces its rights in the database by litigating against companies who trespass without authorization. eBay, Inc. v. Bidder's Edge, Inc., 100 F. Supp. 2d 1058, 1062-63 (N.D. Cal. 2000). Bidder's Edge made copies of eBay's database information. Id. eBay first brought an action under copyright theory against Bidder's Edge, but a database is not entitled to protection under copyright law. Id. at 1072. eBay amended its case and asserted a cause of action under the theory of trespass to chattel and prevailed. Id. at 106970 .

158. See Montgomery, supra note 151 , at 399 (noting that the security agreement is the contract between the parties).

159. U.C.C. §9-203 (2003). Section (a) states that "[a] security interest attaches to collateral when it becomes enforceable against the debtor with respect to the collateral." Id. $\S 9-203$ (a). Section (b) indicates that "a security interest is enforceable against the debtor and third parties with respect to the collateral only if" (1) value has been given by the creditor to the debtor; (2) "the debtor has rights in the collateral or the power to transfer rights in the collateral" to the creditor; and (3) the debtor has authenticated a security agreement that provides a description of the collateral. Id. $\S 9-203(\mathrm{~b})$. 
Article 9 specifies that a security interest attaches when it is enforceable, ${ }^{160}$ that is, when three conditions are satisfied. First, the debtor must have either a right in the collateral or the power to transfer rights in the collateral. ${ }^{161}$ Under article 9, the debtor need not have an ownership right in the collateral in order to grant a security interest to the creditor. ${ }^{162}$ Obviously, the extent to which a creditor's security interest attaches is limited by whatever rights in the collateral the debtor may have. ${ }^{163}$ The grant of a security interest in the collateral, however, does not amount to a transfer of ownership in the collateral. ${ }^{164}$ The second condition is that the creditor must provide value to the debtor. ${ }^{165}$ Value can be in the form of a loan or extension of credit to the debtor. ${ }^{166}$ Finally, the debtor must authenticate the security agreement, which contains a description of the collateral. ${ }^{167}$ In satisfying the three conditions for attachment, the security agreement, at a minimum, must include provisions pertaining to the loan or credit

160. Id. § 9-203(b).

161. Id. § 9-203(b)(2).

162. Id. $\S 9-203 \mathrm{cmt} .6$ (stating that "[a] debtor's limited rights in collateral, short of full ownership, are sufficient for a security interest to attach"). Article 9 requires that the debtor have rights in the collateral or power to transfer such rights. Id. $\S 9-203$ (b)(2). Article 9, however, does not define "rights in the collateral." The extent of the "rights" is generally determined under article 2, if the claimed security interest relates to a sale of goods. See Conister Trust Ltd. v. Boating Corp. of Am., No. M1998-00949-COA-R3-CV, 2002 WL 389864, at *12 (Tenn. Ct. App. Mar. 14, 2002) ("In general, the debtor's 'rights in the collateral' are determined not by Article 9, but by Articles 2, 2A, by the common law, and by other rules.').

163. The security interest, however, attaches only to "whatever rights a debtor may have, broad or limited as those rights may be." U.C.C. $\$ 9-203 \mathrm{cmt} .6$.

164. See id. §9-201 (stating that title to collateral is immaterial to the debtor's and creditor's rights and obligations under article 9); Lois R. Lupica, Asset Securitization: The Unsecured Creditor's Perspective, 76 TEX. L. REv., 595, 656 (1998) (noting that article 9 distinguishes between sales of assets and the grant of security interests in the debtor's assets).

165. U.C.C. $\S 9-203(b)(1)$. Value is given by the secured party to the debtor or obligor. Id. §9-102(a)(59) (defining "obligor" as "a person that, with respect to an obligation secured by a security interest in ... the collateral, owes payment or other performance of the obligation").

166. See id. $\S 9-203(\mathrm{~b})$. Value is defined in U.C.C. $\S 1-204$ (2003). A person gives "value" for rights if he or she acquires them:

(1) in return for a binding commitment to extend credit or for the extension of immediately available credit, whether or not drawn upon and whether or not a charge-back is provided for in the event of difficulties in collection;

(2) as security for, or in total or partial satisfaction of, a preexisting claim;

(3) by accepting delivery under a preexisting contract for purchase; or

(4) in return for any consideration sufficient to support a simple contract.

Id. § 1-204; see also Reade H. Ryan, Jr., Opinions Covering Personal Property Security Agreements, SG023 ALI-ABA 325, 341 (discussing what constitutes value within the meaning of article 9).

167. U.C.C. $\S 9-203(b)(3)(A)$. 
commitment from the creditor, the debtor's right in the collateral, a description of the collateral, and signature blocks for both the debtor and creditor. ${ }^{168}$

Article 9 requires that the description must reasonably identify the collateral. ${ }^{169}$ That condition is met if the security agreement describes the collateral by categorizing it as "a type of collateral defined in [the Uniform Commercial Code]." "170 For example, a security agreement might state that the collateral includes "equipment," "inventory," "farm products," "instruments," and "general intangibles." "171 This means that if the parties intend to use a consumer database as collateral, they can either use the term "general intangible," as permitted under the statute, or create a more specific description of the collateral by using the term "consumer database," "customer lists and information," or "computer database."172 Either usage is sufficient and binds the parties to the contractual security interest agreement. ${ }^{173}$

168. See Ryan, Jr., supra note 166 , at 338-42 (discussing what counsel should state in their opinions relating to the security agreement).

169. U.C.C. $\$ 9-108(b)(3)$ (stating that "a description of collateral reasonably identifies the collateral if it identifies the collateral by ... a type of collateral defined in" article 9 of the Uniform Commercial Code); see also Ryan, supra note 166, at 339 (listing various types of collateral defined in the Uniform Commercial Code that satisfy the sufficiency of description of the collateral requirement).

170. U.C.C. $\S 9-108(b)(3)$.

171. See Ryan, supra note 166, at 339 (providing examples of different types of collateral).

172. The security agreement's collateral description sets the outer limits of the collateral coverage as agreed between the debtor and the secured party. In re Levitz Ins. Agency, Inc., 152 B.R. 693, 697 (Bankr. D. Mass. 1992) ('No matter how broad the financing statement language, the security interest extends no further than the security agreement description." (citation omitted)). If the parties intend to have all assets that fit under the description of "general intangibles" serve as collateral, then the description suits the intent. Id. If the parties intend to limit the collateral to only a specific asset, the parties should name the asset. Id.; see also Raymond T. Nimmer, Bankruptcy and Financing Issues in Intellectual Property Law, in Representing Technology Companies IN THE New Business ENVIRONMENT 485, 494 (PLI Intellectual Prop. Course Handbook Series No. G-683, 2001). ("Under Revised Article 9, a debtor can encumber all of its interests in intellectual property by a security agreement stating: 'general intangibles, current and after-acquired." (footnote omitted)).

173. See Whirlpool Corp. v. Dailey Constr., Inc., 429 S.E.2d 748, 751 (N.C. Ct. App. 1993) (noting that a security agreement "is essentially a contract between the creditor and the debtor"); Montgomery, supra note 151, at 399 ("Because the security agreement embodies the contract between the debtor and creditor, the collateral description in the security agreement should reasonably identify the property."). For example, the generic description "general intangibles" used in a security agreement has been held to be sufficient for the description of collateral consisting of trademarks and copyrights. Id.; see also In re Topsy's Shoppes, Inc. of Kan., 131 B.R. 886, 888-89 (Bankr. D. Kan. 1991). 
Under article 9, both the debtor and creditor are free to set the rest of the terms in the security agreement. ${ }^{174}$ For example, the parties may choose to set forth the debtor's obligations, such as sending notice to the creditor if the debtor moves to a new location ${ }^{175}$ or merges with another entity, ${ }^{176}$ or they may impose restrictions on the debtor's ability to grant broad licensing rights to third parties that would diminish the market value of the collateral asset to the secured party. ${ }^{177}$ Also, the parties generally seek to define events which would constitute a default so as to permit the creditor to realize the security interest by repossession of the collateral. ${ }^{178}$ Other desirable terms are the creditor's obligations, choice of forum, and severability. ${ }^{179}$

The principle of freedom of contract allows both the debtor and creditor to negotiate for terms agreeable to the parties. ${ }^{180}$ The public

174. The debtor and secured party are free to set the terms of the security agreement. Article 9, however, does not allow certain rights and duties to be waived in the security agreement. U.C.C. $\S 9-602(2003)$. For example, the secured party has a duty to collect collateral in a commercially reasonable manner, to refrain from a breach of the peace in taking possession of collateral, and to provide an explanation of the calculation of a surplus or deficiency. Id. $\S 9-602 \mathrm{cmt} .3$.

175. A secured party would like to receive such notice because article 9 requires that, in order for a perfected security interest to continue, a new financing statement must be filed within a certain period of time in the jurisdiction where the debtor has relocated. See id. $\S 9$ 316(a) (providing that a security interest perfected under the law of one jurisdiction remains perfected for a fixed period time, four months or one year, depending on the circumstances). The secured party must reperfect its security interest, typically by filing under the law of the jurisdiction where the debtor has relocated. Id. § 9-316 cmt. 2.

176. When a debtor merges with another entity, a change of the debtor's name may occur. Such a change may render the filed financing statement "seriously misleading," requiring the secured party to amend the original financing statement within a fixed period of time. Id. § 9-508(b).

177. Restrictions on the debtor's licensing rights are permissible as long as such restrictions do not impair or interfere with the debtor's daily business operations. See Paul J.N. Roy, John P. Brockland \& John F. Lawler, Security Interests in Technology Assets and Related Intellectual Property: Practical and Legal Considerations, COMPUTER LAW., Aug. 1999, at 3, 20 (discussing various provisions for inclusion in the drafting of security agreements).

178. Barkley Clark, Revised Article 9 of the UCC: Scope, Perfection, Priority, and Default, 4 N.C. BANKING INST. 129, 165 (2000) (stating that U.C.C. article 9 does not define default, "leaving that critical term to definition by the parties in their security agreement").

179. U.C.C. $\$ 9-602 \mathrm{cmt} .3$ (listing various rights and duties that cannot be waived by the parties in the security agreement).

180. See Tallal v. Bank One, N.A., 767 N.E.2d 275, 276 (Ohio Ct. App. 2001) (stating that the terms of an unambiguous security agreement are binding on the parties); Ben Carpenter, Security Interests in Deposit Accounts and Certificates of Deposit Under Revised UCC Article 9, 55 CONSUMER FIN. L.Q. REP. 133, 137 (2001) (noting that the security agreement must exist for the security interest to be enforceable, but that it may be "created orally, or through implication, course of dealing, a change in terms notice, or any other method sufficient to create a binding contract"); Paula Morris \& Bradley Jensen, Protection of Intellectual Property Rights Against Bankruptcy, 80 J. PAT. \& TRADEMARK OfF. SOC'Y 
generally does not have knowledge of the terms of the security agreement because article 9 does not require the parties to file the security agreement with the Secretary of State's office. ${ }^{181}$ The security agreement is a private contract between the parties. ${ }^{182}$

\section{B. The Financing Statement}

The only document for which article 9 requires filing in a public office is the financing statement. ${ }^{183}$ Under article 9, however, the financing statement must disclose only the names of the parties and a generic statement indicating the collateral, such as "all debtor's assets other than automobiles." 184 The generic indication of the collateral serves the sole function of providing notice to the public that the debtor's personal property assets are obligated as collateral in the secured transaction with the party named in the financing statement. ${ }^{185}$ Article 9 does not require that the financing statement reveal the specific types of the debtor's personal property assets. ${ }^{186}$ Such

779,780 (1998) (stating the importance of advising clients to become secured creditors by executing a security agreement in a legal and binding manner).

181. The financing statement, also known as the U.C.C.-1 form, must be filed for perfection of the security interest. See Chemical Bank v. Sec. Pac. Nat'l Bank, 20 F.3d 375, 378 (9th Cir. 1994) (stating that the failure of the agent of the secured party to file a new financing statement creates "a real risk for its principals").

182. See generally Tallal, 767 N.E.2d at 276 (holding that the security agreement did not place any obligation upon Bank One to manage or supervise Tallal's funds, but did require Tallal to pledge securities worth $\$ 1$ million as collateral for a loan Bank One provided to Tallal and to guarantee that the pledged securities did not decrease in value below $\$ 1$ million); In re Gagle, 230 B.R. 174, 185 (Bankr. D. Utah 1999) (noting that the security agreement is the underlying contract between the parties).

183. U.C.C. $\$ 9-501$ (stating that, except when collateral is as-extracted collateral, timber to be cut, or fixtures, the financing statement is to be filed with the Office of the Secretary of State).

184. Id. §9-502(a)(2); see also Montgomery, supra note 151, at 399 (stating that a "financing statement need only (1) provide the name of the debtor; (2) provide the name of secured party or representative of secured party and (3) indicate the collateral covered by the financing statement").

185. Steven O. Weise, U.C.C. Article 9: Personal Property Secured Transactions, 56 BUS. LAw. 1835, 1844 (2001) (noting that "a financing statement is designed to provide a ready method of providing notice to third parties through a public filing system"); Todd J. Janzen, Note, Nationalize the Revised Article 9 Filing System: A Comparison of the Old Article 9 and Canadian Personal Property Filing Systems, 11 IND. INT'L \& COMP. L. Rev. 389,406 (2001) (stating that the financing statement as a notice "merely indicates that a person may have a security interest in the collateral specified in the financing statement, nothing more").

186. U.C.C. § 9-502(a) (stating that the content of a financing statement must include the identity of the debtor, the identity of the creditor, and an indication of the collateral). The official comment to this section explains that the financing statement as a "notice itself indicates merely that a person may have a security interest in the collateral indicated." Id. $\S 9-502 \mathrm{cmt}$. 2 . 
descriptions of the personal property assets serving as collateral appear only in the security agreement kept by the parties to the contract. ${ }^{187}$

Accordingly, the general public does not have knowledge of the extent to which the security interest reaches the debtor's specific personal assets. ${ }^{188}$ By examining the financing statement filed in a public office, the general public can see only that all debtor's "assets other than automobiles" serve as collateral. ${ }^{189}$ The general public has no idea whether such personal property includes consumer information assets. Even if the financing statement contains a narrower description of the collateral normally required only for the security agreement, the financing statement may reveal only that the collateral is a "general intangible." 190 Again, the public will not know whether "general intangible" means trademarks, patents, accounts, health care receivables, payment intangibles, rights to a tax refund, or consumer databases. ${ }^{191}$ Such detailed information is only included in the security agreement, the private contractual agreement between the parties. ${ }^{192}$ Moreover, as discussed above, article 9 does not require the parties to the security agreement to have a detailed description of the "type of the collateral"; as long as the collateral is identified as a type of collateral, no detailed description is necessary. ${ }^{193}$ Hence, the public

187. See Weise, supra note 185 , at 1843 (stating that the current "Article 9 permits a financing statement (but not a security agreement) to use a general, broad-form description of collateral, such as 'all personal property"' (footnote omitted)). The different requirement for each document exists because each document serves a different purpose: a security agreement is an agreement between the debtor and the creditor, while a financing statement is a notice filing to the public. Id. at $1843-44$.

188. See U.C.C. $\S 9-502 \mathrm{cmt} .2$ (stating that because the financing statement is merely a notice that a person may have a security interest in the collateral indicated, concerned parties may have to conduct further inquiry to obtain "the complete state of affairs"). Article 9 , however, does not provide any statutory procedure to guide how third parties may obtain disclosure. Article 9 only provides a statutory procedure under U.C.C. section 9-210, "under which the secured party, at the debtor's request, may be required to make disclosure." Id. § 9$502 \mathrm{cmt} .2$.

189. Id. $\S 9-504 \mathrm{cmt} .2$ (providing the example illustrating that the phrase "all assets other than automobiles" is sufficient for purposes of indication of the collateral on the financing statement).

190. See id. § 9-5C4 (providing two different ways a financing statement may contain a sufficient indication of the collateral: one way is to have a description of the collateral by type, as in the security agreement, and the other is to have a supergeneric phrase, such as "all assets other than automobiles").

191. See Nicewander, supra note 151, at 169-70 (general intangibles include customer lists and files, trade names, newsletters, liquor licenses, and intellectual property).

192. The contractual document is not required to be filed in order for the security interest to be attached or perfected. See U.C.C. §9-501 (stating which public office is appropriate for the filing of the financing statement).

193. See generally Weise, supra note 110 , at 7 (stating that the new article 9 permits the use of the descriptive phrase "all assets" in a financing statement); Nimmer, supra note 
may still not be able to decipher the parameters of a creditor's security interest, even when the public obtains a copy of the security agreement! ${ }^{194}$

The public is essentially in the dark as to whether consumer names and associated information, profiled information, and other data in the debtor's computer database serve as collateral in various secured financing transactions.

\section{The Debtor's Obligation: The Daily Violation}

1. For the Benefit of the Secured Party

The debtor is obligated under its contractual security agreement with the secured party to maintain the consumer database for the benefit of the secured party. ${ }^{195}$ In a typical security agreement, the debtor agrees to maintain, defend, and preserve the collateral in good condition. ${ }^{196}$ The debtor also furnishes to the secured party statements

172, at 494 ("Under Revised Article 9, a debtor can encumber all of its interests in intellectual property by a security agreement stating: 'general intangibles, current and after-acquired."' (footnote omitted)).

194. Because U.C.C. article 9 provides that a description of the collateral by category or type as defined under article 9 is sufficient, parties to the security agreement can choose to describe the collateral only as "general intangibles." U.C.C. § 9-108(b)(2)-(3). The public, even with a copy of such a security agreement, may not know whether "general intangibles" include the consumer database.

195. When a debtor fails to maintain the collateral, such as by taking parts of the collateral and selling them to third parties, the debtor may be liable to the secured party for conversion. See In re Gagle, 230 B.R. 174, 185 (Bankr. D. Utah 1999) (holding the debtorhusband's actions in selling off parts of the truck collateral constituted conversion). Moreover, if the debtor intentionally injures the creditor's security interest in the collateral property, the debtor's conduct may be held as willful and no discharge of the debt may be allowed by the bankruptcy court. Id. at 179-81; see also Ronald J. Mann, Explaining the Pattern of Secured Credit, 110 HaRv. L. Rev. 625, 651-53 (1997) (discussing various covenants such as those governing the lender's monitoring and inspection of the debtor's collateral assets and those prohibiting the debtor from engaging in certain transactions relating to the collateral assets, and discussing how such covenants serve to protect the collateral assets for the benefit of the lender).

196. See Mann, supra note 195, at 653 (noting that a common provision in secured transactions requires the debtor "to maintain the collateral in good condition and specifies actions that the borrower must perform, such as the maintenance of insurance and the payment of taxes"); see, e.g., Security Agreement between Loislaw.com, Inc. and Wolters Kluwer U.S. Corp. §6(a)(i) (Dec. 19, 2000), available at http://contracts.corporate.findlaw. com/agreements/loislaw/wolters.sec.2000.12.19.html ("Debtor shall preserve and maintain the lien created by this Agreement and will protect and defend its title to the Collateral ...."); Subordinated Loan and Security Agreement between eGroups, Inc. and Comdisco, Inc. § 7.4 (Oct. 8, 1999), available at http://contracts.corporate.findlaw.com/agreements/egroups/ comdisco.loan.1999.10.08.html ("Borrower ... shall at all times keep the Collateral free and clear from any lega[l] process, liens or encumbrances whatsoever ...."); Security Agreement between Storage Technology Corp. and Bank of America, N.A. §5(b) (Oct. 10, 2001), 
and schedules further identifying and describing the collateral in reasonable detail so the secured party can inspect or conduct audits with respect to the collateral. ${ }^{197}$ Essentially, the parties are free to agree upon procedures the debtor must follow to maintain and preserve the collateral and by which the secured party can monitor the collateral. ${ }^{198}$

In light of the public's lack of knowledge about the collateralization of consumer databases, each day the debtor fulfills its obligations under the security agreement to maintain and preserve the consumer database for the benefit of the secured party, the debtor violates principles of consumer privacy embodied in the policy posted on the debtor's Web site. Specifically, the very moment the debtor authenticates the security agreement, the debtor is bound by the contract to maintain and preserve the collateral assets for the benefit of the secured party. ${ }^{199}$ The secured party wants the debtor to fulfill this obligation because the secured party does not want the collateral to diminish in value, causing the loan or credit provided by the secured party to become undersecured. ${ }^{200}$ When the secured party believes that the loan or credit provided to the debtor is undersecured, it may demand an acceleration of the outstanding amount. ${ }^{201}$ Typically, when

available at http://contracts.corporate.findlaw.com/agreements/storagetek/ba.sec.2001.10.10. $\mathrm{html}$ ("The Company will do and perform all reasonable acts that may be necessary and appropriate to maintain, preserve and protect the value of the Collateral."); Security Agreement between Western Multiplex Corp. and Credit Suisse First Boston $\S 5.1$ (Nov. 1, 1999), available at http://contracts.corporate.findlaw.com/agreements/westernmult.plex/ CSFb.sec.1999.11.01.html ("Grantor shall not sell, lease, transfer or otherwise dispose of any of the collateral .....'); Loan Agreement between Intraware, Inc. and Imperial Bank § 9(G) (July 29, 1998), available at http://contracts.corporate.findlaw.com/agreements/intraware/ imperial.loan.1998.07.29.html ("Borrower affirmatively covenants that ... it will ... [p]rovide, maintain and deliver to Bank policies insuring the Collateral against loss or damage ....."); Security Agreement between Schuff International, Inc. and Wells Fargo Bank National Ass'n $\S 5.2$ (Sept. 27, 2001), available at http://contracts.corporate.findlaw.com/ agreements/schuff/wellsfargo.intl.sec.2001.09.27.html ("Debtor shall keep and maintain the Collateral in good condition and repair ....").

197. See Mann, supra note 195, at 651-55 (discussing the lender's monitoring of the debtor's assets and other covenants to reduce the debtor's risky behavior).

198. Indeed Comment 2 to U.C.C. section 9-205 states that "nothing in this section prevents the debtor and secured party from agreeing to procedures by which the secured party polices or monitors collateral or to restrictions on the debtor's dominion. However, this Article leaves these matters to agreement based on business considerations, not on legal requirements." U.C.C. $\$ 9-205 \mathrm{cmt} .2$.

199. See id. §9-201 ("[A] security agreement is effective according to its terms between the parties ....").

200. See Mann, supra note 195, at 651-55 (observing that a lender typically inserts covenants to restrict borrower activities that may jeopardize the assets on which the lender has a lien).

201. See generally In re Citicorp Park Assocs., 180 B.R. 15, 16-18 (Bankr. D. Me. 1995) (finding that the assignment of rent is a collateral security interest that is the property 
the debtor fails to pay, ${ }^{202}$ the secured party may seize the collateral through the repossession process. ${ }^{203}$

\section{Privacy Violations in the Event of Default}

Although the debtor did not sell the collateral outright to the secured party, the secured party through repossession takes complete control of the collateral. ${ }^{204}$ The secured party may keep the collateral and use it in its own business. ${ }^{205}$ The secured party may dispose of the collateral by selling it to others against the outstanding debt owed by the debtor. ${ }^{206}$ For example, in Information Exchange Systems, Inc. $v$. First Bank National Ass'n, the debtor received a loan from a lender. ${ }^{207}$ To secure the repayment of the note, the lender took a security interest

of the debtor, unless the debtor is in default of its obligation and fails to cure the default in a timely manner). Aetna, the secured party in that case, attempted to accelerate the loan and interest of $\$ 8,900,000$, as it deemed its claim was substantially undersecured. Id. at 16-17.

202. Failure to make payments is a typical example of default. The parties to a security agreement, however, are free to define what events will constitute default. For example, the security agreement may define default to include the debtor's sale, disposition, or encumbrance of the collateral without the secured party's consent. Allen v. Simmons Mach. Co., 666 S.W.2d 44, 47-48 (Tenn. 1984) (upholding the lower court's decision that the debtor defaulted on its obligation as stated in the security agreement).

203. See generally In re Carey, 51 B.R. 294, 295 (Bankr. D.D.C. 1985) (stating that a creditor may not repossess the collateral unless there is some future default, such as nonpayment); In re Perry, 25 B.R. 817, 821 (Bankr. D. Md. 1982) ("[S]tate law does not provide the creditor a right to repossess its collateral in the absence of a default."); U.C.C. § 9-609 (stating that after the debtor defaults, a secured party "may take possession of the collateral" by employing the judicial process or self-help, as long as the self-help method is undertaken without breach of the peace).

204. U.C.C. §9-610 ("After default, a secured party may sell, lease, license, or otherwise dispose of any or all of the collateral in its present condition or following any commercially reasonable preparation or processing.").

205. This is strict foreclosure of the collateral. Article 9 encourages strict foreclosures, and sets forth procedures by which the secured party acquires the debtor's rights in the collateral without the need for a sale of the collateral. Id. §9-620. To exercise strict foreclosure, the secured party sends a proposal to accept the collateral in satisfaction of an obligation to the debtor after default. Id. §9-620(a). If the debtor objects, it must state its objection in writing within twenty days after the proposal is sent. Id. $\S 9-620(\mathrm{~d})(1)$. If the secured party does not receive the notification after the twenty-day period, the secured party will exercise strict foreclosure of the collateral. Id. § 9-620(d)(1).

206. Id. § 9-610 (stating methods of disposition of the collateral). The proceeds of the disposition of the collateral are distributed in the following order: (1) the reasonable expenses of retaking, holding, and preparing for disposition (including attorney's fees and legal expenses) incurred by the secured party; and (2) the satisfaction of obligations secured by the security interest under which the disposition is made. Id. §9-615. Any remainder amount will then be distributed to secured parties with junior security interests in the collateral, provided certain conditions are satisfied. Id. § 9-615 (a)(3).

207. Nos. CIV. 4-91-902, CIV. 4-92-224, 1992 WL 494607, at *1 (D. Minn. July 23, 1992), aff'd, 994 F.2d 478 (8th Cir. 1993). 
in the debtor's intellectual property. ${ }^{208}$ The debtor failed to make payment on the note to the lender. ${ }^{209}$ The lender then assigned its right in the note, along with the security interest in the debtor's collateral, to a third party. ${ }^{210}$ Instead of foreclosing on the collateral, the third party took possession of the debtor's assets and exercised strict foreclosure. ${ }^{211}$ The third party then began to use the debtor's intellectual property, including trademarks, copyrights, and patents, to run its own business under the debtor's trademarked name. ${ }^{212}$ The debtor sued the lender for infringement and inducing infringement of intellectual property, but the court held in favor of the lender because the security agreement between the lender and the debtor allowed the lender to assign its security interest in the debtor's collateral assets to third parties. ${ }^{213}$

Here, the consequence of the debtor's collateralization of the consumer database is the repossession of the collateral by the secured party in the event of default. ${ }^{214}$ The secured party can use the consumer database in its business or sell the consumer database to others. ${ }^{215}$ The collateralization of the consumer database and its end result may contradict the debtor's consumer privacy statement declaring that the debtor does not sell or lease the consumer information to others. Though there is no direct sale of the consumer database to the secured party, the effect of the collateralization of the consumer database is the same: the consumer database is in the hands of third parties with unfettered control and rights. ${ }^{216}$ Essentially, the collateralization of consumer databases violates the privacy policies publicized on debtors' Web sites.

208. Id. at *1. Debtor IXI Labs, Inc. and obligor Qwix Media Shops and Depots, Inc. provided a blanket security interest in their assets to secured party First Bank. Id.

209. Id.

210. Id. First Bank sold the Labs and Qwix notes to McNamara after Labs and Qwix failed to make payments on the notes. Id.

211. Id. at *5.

212. Id. at *1, *5. Third party McNamara formed a new entity, Qwix Inc., to operate the business. Id.

213. Id. at *5 (finding that the "security agreements between First Bank and Labs, and First Bank and Qwix, plainly state First Bank's security interests. First Bank simply assigned these ... interests to Fletcher and McNamara").

214. U.C.C. $\$ 9-609$ (2003) (allowing secured party to repossess the collateral).

215. Id. § 9-620 (allowing strict foreclosure of the collateral); Id. §9-610 (allowing the secured party to sell, lease, or dispose of the collateral).

216. See id. $\S \S 9-609,9-610,9-620$. 


\section{Privacy Violations Without Default}

Moreover, even if there is no default event, the consumer privacy statement may be violated nevertheless if the debtor collects, maintains, and preserves the consumer database for the benefit of the secured party pursuant to the contractual agreement. ${ }^{217}$ At all times, from the moment the debtor executes the contract until the time the security interest in the consumer database terminates, the debtor is required to adhere to its obligation to the secured party. ${ }^{218}$ The debtor's fulfillment of its obligation ensures the value of the consumer database so that the secured party can realize the benefit in the collateral when the debtor is in default. ${ }^{219}$ The debtor effectively ignores its own privacy policy statement when it collects and maintains the consumer database. ${ }^{220}$ The debtor maintains and preserves the consumer database during the entire collateralization process for the secured party, even absent a default event, which amounts to collateralization of consumer privacy. ${ }^{221}$

217. It is typical that a security agreement contains provisions relating to the debtor's obligations with respect to the collection, maintenance, and preservation of the collateral. See, e.g., Security Agreement between Loislaw.com, Inc. and Wolters Kluwer U.S. Corp., supra note 196, §6(a)(i); Security Agreement between eGroups, Inc., and Comdisco, Inc., supra note 196, § 7.4; Security Agreement between Storage Technology Corp. and Bank of America, N.A., supra note 196, $\S 5$ (b); Security Agreement between Western Multiplex Corp. and Credit Suisse First Boston, supra note 196, § 5.1; Loan Agreement between Intraware, Inc. and Imperial Bank, supra note 196, $\S 9(\mathrm{G})$; Security Agreement between Schuff International, Inc. and Wells Fargo Bank National Ass'n, supra note 196, § 5.2.

218. Even when a debtor changes its name, the debtor is not discharged of all of its obligations under the security agreement. The secured party does not need to obtain a new security agreement. Jean Wegman Burns, New Article 9 of the UCC: The Good the Bad and the Ugly, 2002 U. ILL. L. REV. 29, 70 n.309 (noting how the security agreement is still binding on the debtor, despite its name change).

219. Obviously, the secured party fears that the debtor "may decrease the value of a security interest by failing to maintain the collateral or otherwise decreasing the value of the collateral." Minh Van Ngo, Agency Costs and the Demand and Supply of Secured Debt and Asset Securitization, 19 YALE J. ON REG. 413, 451 (2002).

220. In a secured transaction, the debtor owes obligations to the secured party. The secured party, by taking a security interest in the consumer database collateral along with the debtor's other assets, wants to increase its chances to receive some return against other creditors, particularly when the debtor is insolvent. Id. at 451 (stating that the benefit of a secured transaction is the increase of "a creditor's expected return in case of debtor insolvency by dedicating a set of assets from the debtor's pool of resources to pay the secured debt").

221. The debtor is required to fulfill its obligation to maintain the collateral during the duration of the security agreement. The debtor's conduct is for the benefit of the secured party. See Mann, supra note 195, at 651-55 (explaining the benefits enjoyed by a secured party compared to an unsecured party). 


\section{Private Default and Public Violation}

Worse yet, default events usually occur out of the public's view. The public does not know when a debtor is in default because conditions constituting default are defined privately between the debtor and the secured party. ${ }^{222}$ The parties are under no obligation to inform the public when a default occurs. ${ }^{223}$ Moreover, the secured party is not obligated by law to inform the public when it plans to seize the collateral. ${ }^{224}$ The secured party does not even have to inform the debtor of the imminent seizure for fear that the debtor may remove the collateral. ${ }^{225}$ Upon seizing the collateral, the secured party is also not obligated to inform the public whether it will keep the collateral ${ }^{226}$ or sell it to third parties. ${ }^{227}$ The public is again kept in the dark as to the fate of the consumer database.

222. As the security agreement is a private contract between the parties, "[i]t is important that the party drafting a security agreement take care to define the event of default that will trigger the secured party's enforcement rights." Lawrence R. Ahern, III, "Workouts" Under Revised Article 9: A Review of Changes and Proposal for Study, 9 AM. BANKR. INST. L. REV. 115, 158 (2001); see also G. Ray Warner, Default and Foreclosure Under Revised Article 9, 19 AM. BANKR. INST. J. 20, 20 (2000) (observing that article 9 does not define default and thus, "the parties must take care to define the elements of default in the security agreement").

223. The public is not a party to the contract and thus not entitled to notice of the debtor's default. Furthermore, article 9 does not even require the secured party to send notice prior to repossession of the collateral upon the debtor's default. See Cheon-Seok Seo, Note, Licenses and the Uniform Computer Information Transactions Act, 1 BUFF. INTELL. PROP. L.J. 146, 161-62 (2001) (noting that though article 9 does not require notice to the debtor upon self-help repossession, the agreement between the parties may require such notice prior to repossession).

224. Nothing in article 9 requires the secured party and/or the debtor to inform the public about default and repossession. The only requirement pertaining to repossession is that the secured party must conduct its repossession without breach of the peace. U.C.C. § 9609 (2003) (describing use of the self-help method without breach of the peace).

225. Article 9 only requires that the secured party taking possession of the collateral after the debtor is in default proceed either through a judicial process or through self-help without breach of the peace. See id. § 9-609. The notice provision is only applicable to the disposition of the collateral. Id. $\S 9-611$ (requiring a secured party disposing of collateral to send "a reasonable authenticated notification of disposition" to certain interested persons).

226. See id. $\S 9-620$ (providing a secured party with the right to exercise strict foreclosure, keeping the collateral in satisfaction of the debt).

227. The secured party is only required to send notice to the debtor and secondary obligor if the secured party is going to dispose of the collateral. Id. §9-611. The secured party is not obligated to send notice to other secured parties who have an interest in the same collateral, except those whom the foreclosing secured party had received written notice of a claim of interest in the collateral. Id. $\S 9-611 \mathrm{cmt}$. 4 (elaborating on the secured party's duty to notify). 
If the secured party decides to exercise strict foreclosure of the collateral, the public does not know. ${ }^{228}$ If the secured party decides to sell the collateral, it may advertise the sale. ${ }^{229}$ This advertisement may be the only way the public learns that the debtor's consumer database is subject to a sale. Under article 9, however, the purpose of advertisement is not to inform the general public, but rather the relevant public with an interest in purchasing the collateral. ${ }^{230}$

\section{PRIVACY REGULATIONS}

\section{A. Industry Self-Regulation and Its Failure}

Currently, there are two approaches to consumer privacy. ${ }^{231}$ Under the approach exercised in the United States, the industry is free to exercise self-regulation. ${ }^{232}$ As alluded to in the previous Parts, under the self-regulation approach, Internet companies post their privacy

228. See id. §9-620 (providing that the secured party send its proposal to exercise strict foreclosure of the collateral only to the debtor and other parties claiming an interest, or security interest, in the collateral).

229. See id. $\S 9-610 \mathrm{cmt} .7$ (stating that the secured party must dispose of the collateral in a commercially reasonable manner, which may include some form of advertisement or public notice of the sale). See generally Michael Korybut, Searching for Commercial Reasonableness Under the Revised Article 9, 87 IOWA L. REV. 1383, 1392-1461 (2002) (discussing the article 9 requirement of "reasonableness" in foreclosure sales).

230. See Michael Korybut, Online Auctions of Repossessed Collateral Under Article 9, 31 RUTGERS L.J. 29, 81 (1999) (observing that some courts have held that notice of the sale of the collateral should be "given to a 'public' reasonably expected to have an interest in the collateral and should be 'published in a manner reasonably calculated to assure such publicity that the collateral will bring the best possible price from competitive bidding of a strived-for lively concourse of bidders"' (footnote omitted)). Thus the general public may not even know about the potential sale of the collateral because the general public may not be the relevant public that would purchase the collateral. Id.

231. There have been for some time two schools of thought on privacy. See Lynn Chuang Kramer, Comment, Private Eyes Are Watching You: Consumer Online Privacy Protection-Lessons From Home and Abroad, 37 TEX. INT'L L.J. 387, 389-90 (2002) (analyzing the two theories on privacy). Some treat privacy as a fundamental human right. Id. The European Union adopts such a theory in their approach in addressing consumer privacy in the Internet. Id. at 390 . Others treat privacy as a commodity. Id. at 389-90. The United States' approach to privacy is rooted in this school of thought. Id. Indeed, U.S. privacy experts have viewed information as a form of property and have adopted various market-based approaches to solve on-line consumer privacy difficulties. See, e.g., Murphy, supra note 55, at 2416 (recognizing information as property and advocating contract default rules prohibiting the disclosure of information); Jerry Kang, Information Privacy in Cyberspace Transactions, 50 STAN. L. REv. 1193, 1266-67 (1998) (viewing personal information as personal property and asserting the use of a contract default rule that would allow individuals to control, sell, or disclose their information).

232. See generally Huie, supra note 74 , at $406-24$ (observing that the U.S. privacy paradigm is constructed through piecemeal legislation and discussing the FTC's role in encouraging the industry's self-regulatory approach). 
policy statements and assert that they adhere to such statements. ${ }^{233}$ The FTC monitors Internet companies' conduct to ensure that such statements are followed. ${ }^{234}$

Unfortunately, as seen in both the Toysmart.com and DrKoop.com cases discussed above in Part II(D), a governmental agency's power to protect consumer privacy is very limited. First, there is no comprehensive regulation on consumer privacy that explicitly prohibits or limits on-line companies' practices regarding consumer databases. ${ }^{235}$ Second, a company's own privacy policy posted on its Web site does not prevent it from selling a consumer database, as long as it adequately discloses the possibility of such an action or secures the consumers' consent for a sale or transfer of information at the time the company collects such information. ${ }^{236}$ Third, as long as a company is in compliance with the privacy policy posted on its own Web site, the company is not engaging in any deceptive practices. ${ }^{237}$ Indeed, many on-line companies have adopted such an approach by asserting in their posted privacy policy statement that the company will not sell, share, or license customer information to others in ways different from those disclosed in the policy. ${ }^{238}$ Companies can later change their practices relating to consumer information without violating the originally posted privacy policy statements. $^{239}$ For example, Amazon.com amended its privacy policy

233. See generally Scott Killingsworth, Minding Your Own Business: Privacy Policies in Principle and in Practice, 7 J. INTEll. Prop. L. 57, 82-88 (1999) (discussing how selfregulation privacy policies are formulated and implemented).

234. See Kennedy \& Wong, supra note 83, at $39-40$ (noting the limitations of FTC settlements in consumer privacy cases such as Toysmart).

235. See generally Huie, supra note 74 , at $403-04$ (stating that there is no comprehensive consumer privacy law, but instead a patchwork of statutes such as the Identity Theft and Assumption Deterrence Act, Children's Online Privacy Protection Act of 1998 (COPPA), and the Electronic Signature Act, along with various national laws containing isolated privacy provisions).

236. See Kennedy \& Wong, supra note 83, at 39-40 (noting how companies can sell consumer information as long they disclose the practice on their privacy policy postings).

237. Id. As long as the on-line company discloses its practice, it is not in violation of the federal deceptive trade practice laws. See Jeff Sovern, Protecting Privacy with Deceptive Trade Practices Legislation, 69 FORDHAM L. REv. 1305, 1321-50 (2001) (analyzing the Federal Trade Commission Act and arguing that the collection and sale of personal information without the knowledge and consent of the person from whom a corporation collects the information may violate the Federal Trade Commission Act).

238. See, e.g., Network Advertising Initiative, NAI Privacy Policy, at http://www. networkadvertising.org/aboutnai_privacy.asp (last visited Sept. 27, 2003).

239. The FTC investigated Amazon.com, Inc.'s amended privacy statement, but found that the new policy does not constitute a deceptive practice. See Kennedy \& Wong, supra note 83, at 29 (reporting the FTC's conclusion that Amazon.com had not violated prohibitions against deceptive or unfair practices); see also Letter from Jodie Bernstein, Director, Federal 
to allow it to transfer customer information, along with other corporate assets, if it sold a part or all of its business. ${ }^{240}$

The self-regulation approach essentially allows on-line companies to freely collateralize privacy because, after all, on-line companies are not directly selling the consumer information to third parties. Hence, self-regulation superficially does not violate privacy policies disseminated on Web sites. Underneath, however, these statements are deceptive; they mislead consumers because the on-line companies nevertheless fail to disclose the collateralization of the consumer database, the consequences of collateralization, including that the consumer database may be seized by a secured party, and the maintenance of the consumer database by the on-line party for the benefit of a secured party during the entire term of collateralization. ${ }^{241}$ The seemingly pervasive nature of the collateralization of privacy makes a mockery of the self-regulation approach, as governmental agencies monitor only the surface of privacy policies statements.

\section{B. The European Union's Approach \& Its Failure}

On the opposite side of the spectrum from the self-regulation approach, the European Union has imposed a stringent consumer privacy directive for companies to observe. ${ }^{242}$ The E.U. Data Privacy Directive recognizes privacy as a fundamental human right. ${ }^{243}$ The Directive defines "processing of personal data" or "processing" to mean "any operation or set of operations which is performed upon

Trade Commission Bureau of Consumer Protection, to Jason Catlett, President, Junkbusters Corporation, and Marc Rotenberg, Executive Director, Electronic Privacy Information Center (May 24, 2001), available at http:/www3.ftc.gov/os/closings/staff/amazonletter.htm (conveying results of an FTC investigation to consumer groups who had requested an inquiry and enforcement action against Amazon.com, Inc.).

240. Amazon.com's new privacy statement now includes a warning that, "in the unlikely event that Amazon.com, Inc., or substantially all of its assets are acquired, customer information will of course be one of the transferred assets." Amazon.com, Inc., Amazon.com Privacy Notice, at http://www.amazon.com/exec/obidos/tg/browse/-/468496/104-11900695471903 (last updated Apr. 3, 2003); Gallagher, supra note 49, at 373.

241. See supra Part IV.C.

242. See generally Huie, supra note 74 , at 396 (comparing the EU and U.S. privacy approaches). Consumers in the EU have access to data about themselves, the right to alter their data, and the right to "opt-in," whereas consumers in the United States have "only the chance, if at all, to 'opt-out' of coverage, and little power to prevent personal data in public records from being collected and re-sold to third parties without their knowledge and consent." Id.

243. The main objective of the EU Privacy Directive was to "protect the fundamental rights and freedoms of natural persons, and in particular their right to privacy with respect to the processing of personal data." Council Directive 95/46/EC, art. 1 (1), 1995 O.J. (L 281) 31,38 . 
personal data, whether or not by automatic means, such as collection, recording, organization, storage, adaptation or alteration, retrieval, consultation, use, disclosure by transmission, dissemination or otherwise making available, alignment or combination, blocking, erasure or destruction. ${ }^{244}$ It requires that (1) personal data should be collected only "for specified, explicit and legitimate purposes"; ${ }^{245}$ (2) the individuals concerned should be fully informed of the purpose and the identity of the data controller; ${ }^{246}$ (3) companies obtain individual consent for the gathering and dissemination of personal data $^{247}$ (4) individuals retain a right to access the collected data, to

244. Id. art. 2(b), 1995 O.J. (L 281) at 38.

245. Id. art. 6, 1995 O.J. (L 281) at 40. Article 6 states, in relevant part:

1. Member States shall provide that personal data must be:

(a) processed fairly and lawfully;

(b) collected for specified, explicit and legitimate purposes and not further processed in a way incompatible with those purposes. Further processing of data for historical, statistical or scientific purposes shall not be considered as incompatible provided that Member States provide appropriate safeguards;

(c) adequate, relevant and not excessive in relation to the purposes for which they are collected and/or further processed;

(d) accurate and, where necessary, kept up to date; every reasonable step must be taken to ensure that data which are inaccurate or incomplete, having regard to the purposes for which they were collected or for which they are further processed, are erased or rectified;

(e) kept in a form which permits identification of data subjects for no longer than is necessary for the purposes for which the data were collected or for which they are further processed. Member States shall lay down appropriate safeguards for personal data stored for longer periods for historical, statistical or scientific use.

2. It shall be for the controller to ensure that paragraph 1 is complied with.

Id.

246. Id. art. 10, 1995 O.J. (L 281) at 41 . Article 10 provides that

[m]ember States shall provide that the controller or his representative must provide a data subject from whom data relating to himself are collected with at least the following information, except where he already has it:

(a) the identity of the controller and of his representative, if any;

(b) the purposes of the processing for which the data are intended;

(c) any further information such as

-the recipients or categories of recipients of the data,

-whether replies to the questions are obligatory or voluntary, as well as the possible consequences of failure to reply,

- the existence of the right of access to and the right to rectify the data concerning him in so far as such further information is necessary, having regard to the specific circumstances in which the data are collected, to guarantee fair processing in respect of the data subject.

Id.

247. Id. art. 7, 1995 O.J. (L 281) at 40. Article 7 provides that

[m]ember States shall provide that personal data may be processed only if: 
rectify incomplete or inaccurate data, ${ }^{248}$ and to object to the collection of the data in the first place $;^{.49}$ and (5) appropriate remedies, such as

(a) the data subject has unambiguously given his consent; or

(b) processing is necessary for the performance of a contract to which the data subject is party or in order to take steps at the request of the data subject prior to entering into a contract; or

(c) processing is necessary for compliance with a legal obligation to which the controller is subject; or

(d) processing is necessary in order to protect the vital interests of the data subject; or

(e) processing is necessary for the performance of a task carried out in the public interest or in the exercise of official authority vested in the controller or in a third party to whom the data are disclosed; or

(f) processing is necessary for the purposes of the legitimate interests pursued by the controller or by the third party or parties to whom the data are disclosed, except where such interests are overridden by the interests for fundamental rights and freedoms of the data subject which require protection under Article 1(1).

Id.

248. Id. art. 11, 1995 O.J. (L 281) at 41-42. Article 11 states:

Information where the data have not been obtained from the data subject

1. Where the data have not been obtained from the data subject, Member States shall provide that the controller or his representative must at the time of undertaking the recording of personal data or if a disclosure to a third party is envisaged, no later than the time when the data are first disclosed provide the data subject with at least the following information, except where he already has it:

(a) the identity of the controller and of his representative, if any;

(b) the purposes of the processing;

(c) any further information such as

- the categories of data concerned,

- the recipients or categories of recipients,

- the existence of the right of access to and the right to rectify the data concerning him in so far as such further information is necessary, having regard to the specific circumstances in which the data are processed, to guarantee fair processing in respect of the data subject.

2. Paragraph 1 shall not apply where, in particular for processing for statistical purposes or for the purposes of historical or scientific research, the provision of such information proves impossible or would involve a disproportionate effort or if recording or disclosure is expressly laid down by law. In these cases Member States shall provide appropriate safeguards.

Id.

249. Id. art. 14, 1995 O.J. (L 281) at 42-43. Article 14 provided that

[m]ember States shall grant the data subject the right:

(a) at least in the cases referred to in Article 7(e) and (f), to object at any time on compelling legitimate grounds relating to his particular situation to the processing of data relating to him, save where otherwise provided by national legislation. Where there is a justified objection, the processing instigated by the controller may no longer involve those data;

(b) to object, on request and free of charge, to the processing of personal data relating to him which the controller anticipates being processed for the purposes of direct marketing, or to be informed before personal 
compensation and damages, must be available before national courts to individuals whose rights under the directive are violated. ${ }^{250}$

The Directive aims to balance an individual's fundamental right to privacy with the free flow of information across borders. ${ }^{251}$ By fostering consumer confidence and minimizing differences among E.U. Member States' national laws regarding personal data protection, the Directive facilitates the development of electronic commerce. ${ }^{252}$

Though the E.U. Directive is generally viewed as the better model of consumer privacy protection, ${ }^{253}$ it fails to address the collateralization of consumer databases. $^{254}$ It is unclear from the

data are disclosed for the first time to third parties or used on their behalf for the purposes of direct marketing, and to be expressly offered the right to object free of charge to such disclosures or uses.

Member States shall take the necessary measures to ensure that data subjects are aware of the existence of the right referred to in the first subparagraph of (b).

Id.

250. Id. art. 22, 1995 O.J. (L 281) at 45. Article 22 states:

Remedies

Without prejudice to any administrative remedy for which provision may be made, inter alia before the supervisory authority referred to in Article 28, prior to referral to the judicial authority, Member States shall provide for the right of every person to a judicial remedy for any breach of the rights guaranteed him by the national law applicable to the processing in question.

Id.

Article 23 states:

Liability

1. Member States shall provide that any person who has suffered damage as a result of an unlawful processing operation or of any act incompatible with the national provisions adopted pursuant to this Directive is entitled to receive compensation from the controller for the damage suffered.

2. The controller may be exempted from this liability, in whole or in part, if he proves that he is not responsible for the event giving rise to the damage.

Id. art. 23, 1995 O.J. (L 281) at 45.

Article 24 states:

Sanctions

The Member States shall adopt suitable measures to ensure the full implementation of the provisions of this Directive and shall in particular lay down the sanctions to be imposed in case of infringement of the provisions adopted pursuant to this Directive.

Id. art. 24, 1995 O.J. (L 281) at 45.

251. See id. pmbl. para. 3, 1995 O.J. (L 281) at 31.

252. Id.

253. See generally, Huie, supra note 74, at 396 ("[T] surprisingly is far ahead of the U.S. in the matter of on-line privacy protection.").

254. The Directive defines "processing of personal data" to mean "any operation or set of operations which is performed upon personal data, whether or not by automatic means, such as collection, recording, organization, storage, adaptation or alteration, retrieval, consultation, use, disclosure by transmission, dissemination or otherwise making available, 
Directive whether consumers must be informed of the use of a consumer database as collateral in secured transactions, or whether the consumers' consent is required for the collateralization. ${ }^{25 s}$ The use of a consumer database as collateral in a secured transaction is not as transparent as the sale or license of a consumer database, and thus a debtor may argue that the collateralization does not fall within regulations pertaining to "processing" of the consumer database. ${ }^{256}$ Further, because the debtor has possession of the collateralized database during the term of the security contract, there is again arguably no direct transfer or dissemination of the consumer database to the secured party. ${ }^{257}$ Accordingly, companies may faithfully follow the E.U. Privacy Directive, yet collateralize consumer privacy in the same way as those companies which adhere to the self-regulation approach in the United States.

\section{Facing the Privacy Dilemma: A Proposal}

Secured transactions are a fundamental business-financing strategy and have an important role in the economy at all levels-local, national, and global. ${ }^{258}$ To that end, article 9 of the Uniform Commercial Code has greatly expanded the scope of secured transactions by recognizing intangible assets as valuable corporate assets that can be used as collateral in secured transactions. ${ }^{259}$

alignment or combination, blocking, erasure or destruction." Council Directive 95/46/EC, art. 2(b), 1995 O.J. (L 281) at 38. The definition is silent on collateralization of data.

255. It seems that the Directive addresses mainly the use of consumer data in direct marketing. Indeed, the Directive only mentions that the consumer has the right to object

to the processing of personal data relating to him which the controller anticipates being processed for the purposes of direct marketing, or to be informed before personal data are disclosed for the first time to third parties or used on their behalf for the purposes of direct marketing, and to be expressly offered the right to object free of charge to such disclosures or uses.

Id. art. 14(b), 1995 O.J. (L 281) at 43.

256. See supra note 254 (providing the definition of "processing" under the Directive).

257. Id. (processing includes use, disclosure, and dissemination of data).

258. See Mann, supra note 195, at 627 ("Granting collateral to secure loans is a dominant feature of this country's commerce: domestic lenders currently hold about two trillion dollars in secured debt.").

259. See Daniel B. Ritter, Revised UCC Article 9: A New Law for Secured Transactions, 54 CONSUMER FIN. L.Q. REP. 147, 147 (2000) (stating that article 9 has expanded greatly). The expansion of article 9:

- accommodates technological developments such as software financing and electronic commerce; 
Companies, particularly on-line companies with little or no tangible assets, will continue to use general intangibles, including consumer databases, as collateral in their financing transactions with secured creditors. ${ }^{260}$

Regarding the collateralization of privacy on the one hand, an Internet-company debtor that collateralizes its consumer databases may be under a contractual obligation to collect, aggregate, and maintain the consumer database at all times for the benefit of the secured party until it pays the original loan or meets the obligation. ${ }^{261}$ In the event of the debtor's default, the secured party can possess and keep the consumer database or sell it to others in satisfaction of the outstanding loan or obligation. ${ }^{262}$ On the other hand, the consumer is not placed on notice by the privacy policy statement concerning the collateralization of a consumer database and its consequences. ${ }^{263}$ The conduct of the Internet-company debtor and the secured party pursuant

- simplifies the filing system-for example, it specifies a national form of financing statement and designates the debtor's location as the place to file against most tangible as well as intangible collateral;

- $\quad$ expands the scope of Article 9 to cover more types of collateral (for example, commercial deposit accounts) and more transactions (for example, asset securitizations);

- adds some new rules for consumer transactions;

- provides more detailed rules on nonjudicial enforcement of security interests, including safe-harbors as well as additional requirements; and

- clarifies and elaborates prior law to fill in gaps, eliminate ambiguities, and resolve conflicts in judicial interpretation.

Id.

260. See Kaufman, supra note 67, at 95 (noting that e-commerce assets are general intangibles and counseling how a security interest in such assets can be preserved through perfection). The perfection of a security interest in consumer data, a general intangible, is achieved by filing the financing statement. Id. A caution to the drafter of a security agreement: "not[e] the possible restrictions on sale or other transfer of such data to the extent provided by law or the terms of confidentiality policies under which the data was obtained." Id.

261. See U.C.C. $\S 9-201 \mathrm{cmt} .2$ (2003) ("[A] security agreement is effective between the debtor and secured party and is likewise effective against third parties.").

262. See id. U.C.C. §9-609 (repossession); id. § 9-610 (disposition of collateral); id. $\S 9-620$ (strict foreclosure of collateral).

263. Privacy policy statements are silent on the collateralization of consumer databases. For examples of privacy statements, see the Web sites of Yahoo! Inc., supra note 88; Amazon.com, Inc., supra note 88; Travelocity.com LP, supra note 88; Microsoft Corporation, ABC. Inc., supra note 88; VeriSign, Inc., supra note 88; Expedia, Inc., supra note 88; Best Fares USA, Inc., at http://www.bestfares.com; and RealNetworks, at http://www.realnetworks.com. 
to the terms of the contract are out of the consumer public's view. ${ }^{264}$ The debtor and the secured party are not obligated under article 9 to inform the consumer. ${ }^{265}$

Obviously, prohibiting companies from using consumer databases as collateral in secured transactions is an unworkable and unrealistic solution. Addressing the dilemma of collateralization of privacy instead requires modifications to the existing article 9.

The need to balance consumer privacy with the debtor company's business need to obtain a loan or credit requires some critical modifications of the current, misleading consumer privacy practices. Privacy policy statements should require the on-line company to disclose when a consumer database is used as collateral in secured transactions. ${ }^{266}$ The privacy statement must explain that, as a consequence of such collateralization, the consumer database is at all times collected and maintained for the benefit of secured creditors, it may be in the control of secured creditors, and may be sold to third parties beyond the debtor's control. ${ }^{267}$

This proposal requires modifications in the debtor's and the secured party's obligations in secured transactions under article 9. Article 9 should be amended to require that the financing statement refer to a consumer database if such a database is used as collateral in a secured transaction. ${ }^{268}$ Under such a regime, the public would be able to conduct a search under the debtor's name and learn if the consumer database is being collateralized. ${ }^{269}$ Because a financing statement is

264. Because the parties to the security agreement are engaged in a private contract, the law does not require that the terms be made available to the public. See U.C.C. § 9-501 (providing that only the financing statement, not the security agreement, is required for perfection of security interest by filing).

265. See id. §9-502 (dictating the contents of the financing statement filed with the Secretary of State's office). The financing statement contains basic information about the secured party and the debtor, and a mere indication of the collateral. Id. §9-502.

266. On-line companies should not be allowed to continue hiding behind their privacy policy statements that they are not selling or renting consumer information to third parties while they are granting a security interest in all of their assets to creditors in secured transactions.

267. Without an explanation of collateralization of privacy, the public is not informed of the violation of consumer privacy. See Solove, supra note 1, at 1450-51 (observing that despite the few notable instances of privacy litigation as a response to public outcry, most privacy violations occur outside the public view).

268. Currently, article 9 allows a super-generic statement, such as "all assets other than automobiles," to suffice for the purpose of indication of the collateral on the financing statement. U.C.C. § 9-504 \& cmt. 2.

269. Financing statements are indexed under the debtor's name. A financing statement which fails sufficiently to provide the name of the debtor may be deemed seriously misleading. See id. §9-506(b). 
effective for five years, the public will learn the period of collateralization and the identity of the secured party holding the security interest in the consumer database. ${ }^{270}$

Article 9 should also be amended to require that the security agreement contain a provision relating to consumer privacy if a debtor's consumer database is used as collateral. ${ }^{271}$ The provision would impose on the secured party an obligation to observe the consumer privacy policy adopted by the debtor and posted on its Web site. ${ }^{272}$ Obviously, from a stronger consumer-advocacy position, the provision should require the secured party to send notice to consumers after it takes possession of the consumer database upon the debtor's default. ${ }^{273}$ The consumer should at the least have the choice to optout. ${ }^{274}$

\section{CONCLUSION}

Collateralization of privacy is an invisible, pervasive phenomenon. It is rooted in fundamental financing schemes and facilitated by article 9 of the Uniform Commercial Code. As more institutional investors in the post-dot-com era demand senior secured lender status in relation to an Internet company's intangible assets, ${ }^{275}$ secured transactions involving on-line companies' assets, including

270. See id. $\S 9-515$ (stating that a financing statement is effective for a period of five years after the date of filing, and that a financing statement filed in connection with a publicfinance transaction is effective for a period of thirty years after the date of filing, if it is so indicated).

271. See Kaufman, supra note 67, at 95 (suggesting that drafters of security agreements covering consumer database collateral should pay attention to "the possible restrictions on [the] sale or other transfer of such data to the extent provided by law or the terms of confidentiality policies under which the data was obtained").

272. See id.

273. Because many creditors can have security interests in the same collateral, the public does not have any knowledge as to the identity of the third party (creditor) who physically owns or has unfettered control over the consumer database upon repossession. See U.C.C. $\S 9-611$ (providing that the secured party notifies other secured creditors with interest in the collateral of the disposition of the collateral assets).

274. See Spencer, supra note 48 , at 910 (observing that privacy advocates preferred the opt-in approach). "A meaningful opt-in requirement would combat information asymmetry by mandating plain language notice of what information merchants collect and how they will use it." Id. Under an "opt-out" scheme, data collectors presume consent from the data subject and require the data subject to affirmatively opt-out. See Seagrumn Smith, Microsoft and the European Union Face Off Over Internet Privacy Concerns, 2002 DUKE L. \& TECH. REV. 14.

275. See Marshall, supra note 53 (reporting that the Internet company granted Sand Hill Capital senior secured lender status regarding the security interest in the Internet company's assets that included the domain name and customer list). 
consumer databases, will continue to be a dominant feature in ecommerce. $^{276}$

The Internet consumer privacy problem stemming from the collateralization of customer databases is perhaps part of the larger privacy problem that originates from a "careless and unconcerned bureaucratic process - one that has little judgment or accountabilityand is driven by ends other than the protection of people's dignity."

As both U.S. self-regulation and the E.U. Privacy Directive have failed, it is still not too late for a serious debate encouraging national legislation on consumer privacy that addresses many invisible privacy violations, including the collateralization of privacy. ${ }^{278}$

276. See Standard \& Poor's 2001 Corporate Ratings Criteria 49, available at http:// www.standardandpoors.com/ResourceCenter/RatingsCriteria/CorporateFinance/2001Corpor ateRatingsCriteria.html (last visited Feb. 9, 2002) ("Bank loans to below-investment-grade credits tend to have a first priority security interest in substantially all of a company's assets: receivables, inventory, trademarks, patents, plant, property, equipment, and pledge of subsidiary stock. Private-placement debt issues are more likely to be secured by one or more discrete asset types.").

277. See Solove, supra note 1, at 1429.

278. For a discussion of other obligations and duties that an information-property owner should follow, see generally Jacqueline Lipton, Information Property: Rights and Responsibilities, 56 FLA. L. REV. 135, 181-87 (2004). 